\title{
Magnetostratigraphy of sediments from Lake El'gygytgyn ICDP Site 5011-1: paleomagnetic age constraints for the longest paleoclimate record from the continental Arctic
}

\author{
E. M. Haltia ${ }^{1, *}$ and N. R. Nowaczyk ${ }^{1}$ \\ ${ }^{1}$ Helmholtz Centre Potsdam, GFZ German Research Centre for Geosciences, Section 5.2, Climate Dynamics and Landscape \\ Evolution, Telegrafenberg, 14473 Potsdam, Germany \\ *now at: University of Turku, Department of Geography and Geology, Section of Geology, 20014 Turku, Finland
}

Correspondence to: E. M. Haltia (eeva.haltia@utu.fi)

Received: 31 July 2013 - Published in Clim. Past Discuss.: 3 September 2013

Revised: 17 January 2014 - Accepted: 5 February 2014 - Published: 26 March 2014

\begin{abstract}
Paleomagnetic measurements were performed on sediments drilled from ICDP Site 5011-1 in Lake El'gygytgyn $\left(67^{\circ} 30^{\prime} \mathrm{N}, 172^{\circ} 05^{\prime} \mathrm{E}\right)$ located in Far East Russian Arctic. The lake partly fills a crater formed by a meteorite impact $3.58 \pm 0.04 \mathrm{Ma}$ ago. Sediments from three parallel cores (5011-1A, 5011-1B and 5011-1C), recovered from the middle part of the lake, yield a total of $355 \mathrm{~m}$ of sediment. Sediments are characterized by a variable lithology, where intervals of homogenous and laminated sediments alternate, and mass movement deposits occur frequently along the sediment profile. Mineral magnetic investigation made on sediments enclosed in core catchers suggests that magnetic carrier in these sediments is partly maghemitized Tirich pseudo-single domain magnetite. Its detrital origin can be shown by mineral magnetic measurements and SEM-EDS analyses performed on mini-sized cylindrical rock samples, polished rock sections and creek sediments. The intensity of the natural remanent magnetization in the sediments is high with a range from about 1 to $1000 \mathrm{~mA} \mathrm{~m}^{-1}$. Most of the sediments carry a stable magnetization interpreted as primary depositional remanent magnetization. Characteristic inclination data show alternating intervals of steep positive and negative inclinations that are used to assign magnetic polarity to the lake sediment profile. This is a rather straightforward procedure owing to the mainly high quality of data. The Matuyama/Gauss (M/G) (2.608 Ma) and Brunhes/Matuyama (B/M) (0.780 Ma) reversals were recognized in the sediments. The Mammoth and Kaena reversed subchrons were identified during the Gauss chron, and the
\end{abstract}

Olduvai and Jaramillo normal subchrons as well as the Réunion and Cobb Mountain cryptochrons were identified during the Matuyama chron. Sediments also provide a record of the Olduvai precursor and Intra-Jaramillo geomagnetic excursions. Sediment deposition rate is highest at the base of the sequence laid down in the early Gauss chron, when the deposition rate is approximately $44 \mathrm{~cm} \mathrm{kyr}^{-1}$. Sediment deposition decelerates upcore and it is an order of magnitude lower during the Brunhes chron in comparison with the early Gauss chron. Decrease in sediment deposition in the late Pliocene probably relates to atmospheric and oceanic reorganization heralding the onset of Quaternary climate change. The high-quality magnetostratigraphy reconstructed from Lake El'gygytgyn sediments provides 12 first-order tie points to pin down the age of the longest paleoclimate record from the continental Arctic.

\section{Introduction}

Due to the combination of climate feedback mechanisms related to sea ice and ice sheet albedo, climate in the northern high latitudes is particularly sensitive to seasonal and latitudinal insolation variations on orbital timescales (e.g., Kutzbach et al., 1991). Investigation of long-term climatic history in the continental Arctic has been hindered by a lack of data from high-latitude depositional sites, where continuous sedimentary records extending beyond the termination of the last glacial would have been preserved. Obtaining a long 
and continuous climate record from an Arctic continental site is crucially important in an attempt to reconstruct the character and timing of climatic variability and its environmental response during the Quaternary, or even longer back in time. This would also enable the establishment of climatic teleconnections between records from different archives, such as lacustrine and marine sediments, ice cores, or loess, and add to a more comprehensive understanding of the functioning of the climatic system (Katz et al., 2011).

A pilot study of sediment core PG1351 recovered in 1998 from Lake El'gygytgyn, which occupies a meteorite impact crater in the Far East Russian Arctic, revealed a continuous record of paleoenvironmental variability responding to orbitally driven summer insolation during the last $250 \mathrm{kyr}$ (Brigham-Grette et al., 2007; Nowaczyk et al., 2007). Inferring from geomorphological analysis of end moraines deposited by valley glaciers and associated cosmogenic isotope dating, Far East Russia has not been covered by an ice sheet at least since the Middle Pleistocene (BrighamGrette et al., 2003). This renders the lake an attractive target for drilling a unique and temporally longest continental sediment sequence from the Arctic. With this objective in mind, deep drilling in Lake El'gygytgyn was executed within the framework of the ICDP (International Continental Scientific Drilling Project) Lake El'gygytgyn Drilling Project in the spring of 2009 (Melles et al., 2011). The significance of this unique and continuous paleoclimatic record, which extends into the mid-Pliocene, is summarized by Melles et al. (2012) and Brigham-Grette et al. (2013). Developing an accurate sediment chronology is of key importance in unlocking the climatic record preserved in the sediments from El'gygytgyn. The capability of remanence-carrying iron oxides in sediments and rocks to record geomagnetic polarity variations enables their dating by matching the reconstructed magnetostratigraphic variations with respect to geomagnetic polarity timescales (e.g., Cande and Kent, 1995; Opdyke and Channell, 1996). This paper presents magnetostratigraphic results from this unique Arctic lake, which forms the principal chronological framework for the sediments recovered during the deep drilling of Lake El'gygytgyn. In order to obtain information about the carrier of the paleomagnetic signal and its origin in these sediments, mineral magnetic properties of lake sediments and rock samples and sediments from the catchment were investigated.

\section{Site description}

Lake El'gygytgyn $\left(67^{\circ} 30^{\prime} \mathrm{N}, 172^{\circ} 05^{\prime} \mathrm{E} ; 492 \mathrm{~m}\right.$ a.s.l. - meters above sea level) is a crater lake located in the mountainous central Chukotka Peninsula in the Far East Russian Arctic. According to the most recent results from ${ }^{40} \mathrm{Ar} /{ }^{39} \mathrm{Ar}$ dating, the $18 \mathrm{~km}$-wide crater was formed as a result of a meteorite impact into a mid-Cretaceous silicious volcanic rock series in the middle Pliocene at 3.58 $\pm 0.04 \mathrm{Ma}$ (Layer, 2000).
Dominant rock types include rhyolitic and dacitic tuffs, ignimbrites and lavas, and to a lesser extent, andesitic tuffs and lavas, which are overlain by basalts in the northeastern part of the crater rim (Gurov and Koeberl, 2004). The lake basin is bowl-shaped with steep flanks and a flat bottom, enclosing a lake with a diameter of $12 \mathrm{~km}$, surface area of $110 \mathrm{~km}^{2}$ and maximum depth of $175 \mathrm{~m}$. The catchment $\left(293 \mathrm{~km}^{2}\right)$ is small in relation to the lake surface area and, during summertime, its permafrost soils are drained by ca. 50 ephemeral creeks radially directed with respect to the lake (Fig. 1). The lake has one outlet, the Enmyvaam River, which has cut its way through the crater rim in the southeast and drains into the Bering Sea. Based on the interpretation of refraction- and reflection-seismic data, the layered sediment infill was estimated to have a thickness of 320 to $340 \mathrm{~m}$ (Gebhardt et al., 2006, 2013). This was confirmed by the ICDP drilling, intersecting the transition zone from sediments to impact breccia at a depth of around $316 \mathrm{~m}$. Currently, the lake is oligotrophic and monomictic, and the water column becomes thermally stratified under the ice cover, which persists from October to mid-July. The lake becomes thoroughly mixed by strong winds during the intervening ice-free months (Nolan and Brigham-Grette, 2007). Climate in the Arctic Chukotka Peninsula is continental and according to weather data collected in 2002 the annual mean temperature was $-10.3^{\circ} \mathrm{C}$, with annual extreme values ranging from -40 to $+26^{\circ} \mathrm{C}$ (Nolan and Brigham-Grette, 2007). The sparse vegetation in the area is tundra dominated by herbs and low shrubs (Lozhkin et al., 2007).

\section{Material and methods}

\subsection{Lake drilling and sediment core handling}

As a result of a long-standing planning and international cooperation, sediments and underlying impact breccia were cored within the frame of the ICDP Lake El'gygytgyn Drilling Project from October 2008 to May 2009. Drilling operations and on-site processing of cores are documented in detail by Melles et al. (2011) and here they are only briefly reviewed. Coring was undertaken from an ice platform using the Russian GLAD800 drill rig operated by a US consortium, Drilling, Observation and Sampling of the Earth's Continental Crust Inc. (DOSECC). Sediment cores were drilled from ICDP Site 5011-1 in the flat middle part of the lake $\left(67^{\circ} 29.98^{\prime} \mathrm{N}, 172^{\circ} 6.23^{\prime} \mathrm{E}\right)$ from three parallel holes, 50111A, 5011-1B and 5011-1C (Table 1). For brevity, sediment cores from these holes will be referred to as cores $1 \mathrm{~A}, 1 \mathrm{~B}$ and $1 \mathrm{C}$, respectively. The gradual transition from sediment to underlying impact breccia occurs approximately at 316 meters below the lake floor (Gebhardt et al., 2013). Coring tools were selected according to increasing sediment stiffness with depth, and a hydraulic piston corer, an extended nose corer and an alien bit corer were employed. Rather long intervals 


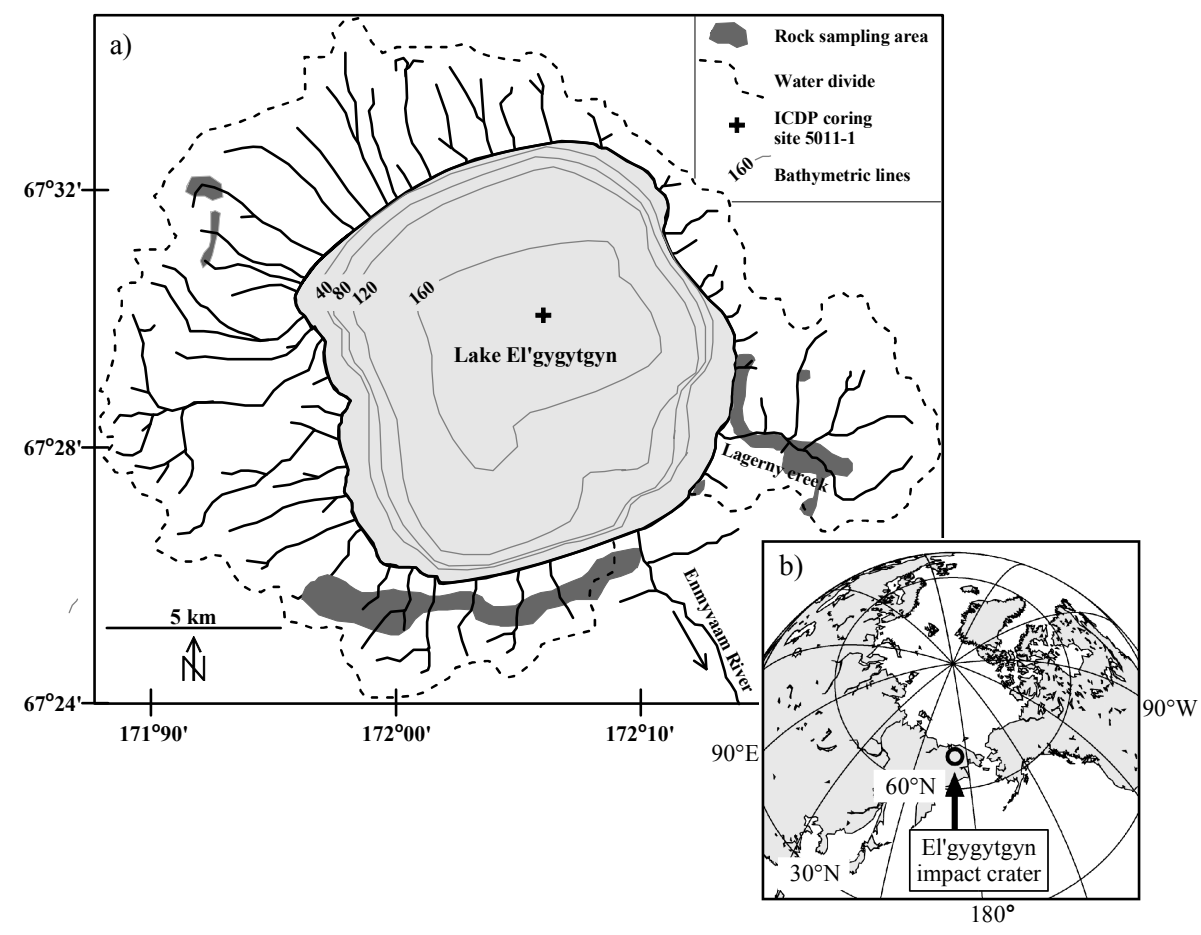

Fig. 1. Schematic map of Lake El'gygytgyn and its catchment (a) and the position of Lake El'gygytgyn in a global context (b). Largest creeks are marked on the map by thick solid lines. The location of ICDP Site 5011-1, in the flat central part of the bowl-shaped lake floor, is marked by a cross. The rim of the impact crater mostly follows the border of the lake's catchment (dashed line).

in core $1 \mathrm{C}$ were hampered by incomplete sediment recovery (Table 1), which may be related to coarse sediment intervals encountered at this part of the sequence and/or the coring tool employed (Melles et al., 2011).

In the laboratory, sediment sections enclosed in liners were cut lengthwise with a circulating saw and subsequently the sediment was split into two halves (i.e., a working half and an archive half) using a nylon string. The consolidated sediments in the bottommost sections recovered from hole 1C were cut lengthwise in half with a circular saw. After opening, a lithological description of the sediments was made and they were subjected to various non-destructive optical, magnetic, geochemical and physical analyses (Melles et al., 2011). Sediments were sub-sampled according to a predefined scheme with consistent aliquots for different types of analyses. A composite sediment record was reconstructed during core processing and sub-sampling of sediments from cores $1 \mathrm{~A}, 1 \mathrm{~B}$ and $1 \mathrm{C}$, which included, among other things, identification of more than 300 mass movement deposits and their exclusion from the final paleoclimate record (Sauerbrey et al., 2013; Wennrich et al., 2013; Nowaczyk et al., 2013).

\subsection{Paleomagnetic sampling and measurements}

The majority of paleomagnetic measurements were made on working halves of sediment sections sampled in u-channels, $2 \times 2 \mathrm{~cm}$ in cross section, either 110 or $75 \mathrm{~cm}$ in length,
Table 1. Information on drilling of sediments from cores 1A, 1B and 1C from ICDP Site 5011-1 in Lake El'gygytgyn. In core 1C sediments were first recoved from 42 to $50 \mathrm{~m}$ (shown in brackets) to patch up gaps in sediment recovery in cores $1 \mathrm{~A}$ and $1 \mathrm{~B}$. After that drilling was continued at a depth of $100.0 \mathrm{~m}$.

\begin{tabular}{lccccc}
\hline \multicolumn{6}{c}{ Drilling of lake sediments on ICDP Site 5011-1 } \\
\hline Core & $\begin{array}{c}\text { Start } \\
(\mathrm{m})\end{array}$ & $\begin{array}{c}\text { End } \\
(\mathrm{m})\end{array}$ & $\begin{array}{c}\text { Drilled } \\
(\mathrm{m})\end{array}$ & $\begin{array}{c}\text { Recovered } \\
(\mathrm{m})\end{array}$ & $\begin{array}{c}\text { Recovery } \\
(\%)\end{array}$ \\
\hline 5011-1A & 2.9 & 146,6 & 143.7 & 132.0 & 92 \\
$5011-1 \mathrm{~B}$ & 3.5 & 111.9 & 108.4 & 106.6 & 98 \\
$5011-1 \mathrm{C}$ & $(42.0) 100.0$ & $(51.0) 316.3$ & 225.3 & 116.1 & 52 \\
\hline
\end{tabular}

depending on sediment recovery in the individual core sections. Paleomagnetic sampling was executed along the pristine central part of the core sections to avoid sheared sediment adjacent to liner walls. Cores $1 \mathrm{~A}$ and $1 \mathrm{~B}$ were sampled continuously using $\mathrm{u}$-channels. The sediments from core $1 \mathrm{C}$ were mainly sampled using paleomagnetic sample boxes ( $n=446$; dimensions $2 \times 2 \times 1.5 \mathrm{~cm}$; volume ca. $\left.6 \mathrm{~cm}^{2}\right)$ in the sediment interval extending from 141.8 to $311 \mathrm{~m}$. Alternatively, u-channel samples were taken where possible. Discrete sampling was made by pushing a sediment sampler with a square cross section and internal dimensions of $1.9 \times 1.9 \mathrm{~cm}$ into the sediment in order to cut a cubical sample, which was then extruded into a paleomagnetic sample box. Discrete sampling was preferred because 
increasing sediment stiffness downcore hampered sampling in u-channels. Moreover, discrete sampling allowed targeting sampling to undisturbed clayey and silty sediments, which have more potential to yield reliable paleomagnetic data than coarser-grained sediments encountered in core 1C. Whenever possible, discrete samples were taken in steps of $10 \mathrm{~cm}$. However, the actual sampling spacing is $12.6 \mathrm{~cm}$, because sand layers and disturbed sediment sections were avoided. Sampling was continued until $311 \mathrm{~m}$. From this depth downwards until $316 \mathrm{~m}$ sediment are highly consolidated gravel and pebbles in a sandy matrix and cutting paleomagnetic samples without disturbing the sediment was not possible. Then again, the sediment was too brittle to be sampled using a rotating diamond drill bit. Therefore, a non-standard sampling technique was applied in order to obtain half-oriented samples with a known vertical orientation but unknown azimuth. In general, the half-cylindrical sediment columns of the archive halves were broken into segments (biscuits) of varying thickness by the coring process. The archive halves were placed directly next to the sample holder of the longcore magnetometer. Then, suitable sediment segments (discs) were individually taken out of the liner for sub-sampling, and a non-magnetic saw blade was used to cut off approximately triangular, partly irregular pieces. The resulting samples, approximately 5 to $8 \mathrm{~cm}^{3}$ in volume, were placed directly in the magnetometer's sample holder in order to avoid misorientation. The employed sample holder has been designed to take up eight cylindrical samples of $10 \mathrm{~cm}^{3}$ that can be fixed by a plastic spring in order to avoid movement or rotation of the samples during measurements. Because the sediment pieces were fairly crumbly they were fitted back into the archive halves directly after measurement of the magnetization and no further magnetic investigation was performed on them.

Natural remanent magnetization (NRM) was measured from all the paleomagnetic samples with a $2 \mathrm{G}$ Enterprises 755-SRM cryogenic long-core magnetometer at the Laboratory for Paleo- and Rock Magnetism in Potsdam, Germany. The NRM was progressively demagnetized in ten steps (5, $10,15,20,30,40,50,65,80$ and $100 \mathrm{mT}$ ) with the magnetometer's inline three-axis demagnetizer and the remaining NRM was measured after each demagnetization step. The direction of the characteristic remanent magnetization (ChRM), i.e., the magnetization component interpreted as carrying primary and supposedly syn-depositional information was isolated using the progressively demagnetized NRM data from five to seven successive AF demagnetization steps picked by the eye using principal component analysis. A measure of precision of fitting the NRM demagnetization data to a line in principal component analysis can be expressed by maximum angular deviation (MAD) (Kirschvink, 1980). MAD angles $\leq 5^{\circ}$ are interpreted as characterizing samples where a single component magnetization has been isolated. The magnetometer's pick-up coils average data over about $9.5 \mathrm{~cm}$. Thus, in order to eliminate spurious results due to edge effects, data collected along the upper and lower $4 \mathrm{~cm}$ of a u-channel were excluded from the final paleomagnetic data.

Unless otherwise stated, ages for the polarity transitions are derived from LR04, which is a benthic foraminiferal oxygen isotope $\left(\delta^{18} \mathrm{O}\right)$ stack with a global distribution of the constituting data (Lisiecki and Raymo, 2005). LR04 is employed here, because the chronological framework provided by magnetic polarity reversals is further refined by tuning of different sedimentary paleoclimate proxies sensitive to climatic and insolation variations in orbital timescales with respect to (1) the LR04 stack or (2) Northern Hemisphere summer insolation (Laskar et al., 2004) as a reference curve (Nowaczyk et al., 2013).

\subsection{Mineral magnetic measurements on catchment rocks, creek sediments and lake sediments}

Investigation of mineral magnetic properties, i.e., the concentration, grain size, and mineralogy of magnetic minerals, is vital for identifying the carrier(s) of remanence in the sediment. Mineral magnetic measurements allow inferences to be made concerning the source of sedimentary magnetic minerals, their depositional environment and diagenetic processes therein. In some cases, post-depositional diagenetic processes and/or growth of secondary authigenesis of magnetic minerals, such as the ferrimagnetic mineral greigite (Fe3S4), may have altered or even completely erased the primary NRM originating from the time of sediment deposition (Snowball, 1991; Dearing et al., 1998; Roberts and Weaver, 2005). Therefore, careful identification of carrier(s) of remanence has important implications for the consideration of the reliability of paleomagnetic dating. A previous study investigating mineral magnetic properties of sediment composite core PG1351 (12.7 m in length, age at the bottom of the composite: $250 \mathrm{ka}$ ) from the central part of Lake El'gygytgyn showed that magnetic susceptibility shows strong cyclic variations with respect to depth (Nowaczyk et al., 2002. Magnetic properties in sediment intervals characterized by high magnetic susceptibility (from ca. $250 \times 10^{-6}$ to $2000 \times 10^{-6}$ ) are dominated by pseudo-single domain (PSD) magnetite, whereas low magnetic susceptibility intervals (from ca. $40 \times 10^{-6}$ to $250 \times 10^{-6}$ ) are dominated by a high coercivity mineral (haematite) in terms of mass percentage, but magnetic properties are still dominated by magnetite, as shown by Verwey transition at ca. $-150^{\circ} \mathrm{C}$ during low-temperature measurements. The available evidence led Nowaczyk et al. (2002) to interpret magnetic susceptibility variations in terms of climate, where low (high) susceptibility values result from magnetite dissolution (preservation) in the anoxic (oxic) bottom conditions during glacials (interglacials). While the sediments from Site 5011-1 sampled in u-channels were considered to be a sediment archive and therefore remain intact, sediment enclosed in core catchers, one in every three meters of sediment, from the cores $1 \mathrm{~A}$ to $1 \mathrm{C}$ was available for a mineral magnetic investigation. 
Table 2. Information on magnetic parameters used to characterize mineral magnetic assemblages in catchment rocks, creek sediments and lake sediments from Lake El'gygytgyn and its catchment. $\mathrm{CR}=$ catchment rocks, $\mathrm{CS}=$ creek sediments and $\mathrm{LS}=$ lake sediments.

\begin{tabular}{|c|c|c|c|c|}
\hline Parameter & Instrument & Unit & Explanation & Notes \\
\hline \multicolumn{5}{|c|}{ Magnetic measurements } \\
\hline $\begin{array}{l}\text { Low-field volumetric } \\
\text { magnetic susceptibility } \\
\kappa_{\mathrm{lf}}\left(\mathrm{SI}, \times 10^{-6}\right)\end{array}$ & $\begin{array}{l}\text { Kappabridge MFK1-A } \\
\text { (AGICO) }\end{array}$ & Unitless & $\begin{array}{l}\text { Used for estimation of concentration of magnetic minerals in } \\
\text { uniform magnetic mineralogy. As an in-field parameter, } \kappa_{\mathrm{lf}} \text { may } \\
\text { be increased by paramagnetic minerals and superparamagnetic } \\
\text { grains, which do not carry remanence. Essentially independent of } \\
\text { magnetite grain size. }\end{array}$ & $\begin{array}{l}\text { Measured from CR, CS } \\
\text { and LS }\end{array}$ \\
\hline $\begin{array}{l}\text { Isothermal remanent } \\
\text { magnetization, IRM }\end{array}$ & $\begin{array}{l}\text { Either (1) for imprinting } \\
\text { the desired field: Impulse } \\
\text { magnetizer ( } 2 \mathrm{G} \text { model } 660 \text { ) } \\
\text { and for the measuring of the } \\
\text { remanence: Minispin } \\
\text { spinner magnetometer } \\
\text { (Molspin Ltd.) or (2) } \\
\text { Alternating field } \\
\text { magnetometer MicroMag } \\
2900 \text { (Princeton } \\
\text { Measurements Corp.) }\end{array}$ & $\mathrm{Am}^{-1}$ & $\begin{array}{l}\text { Magnitude of standalone IRM measurements relates to magnetite } \\
\text { concentration and inversely to magnetite grain size. Observations } \\
\text { of IRM of samples exposed to incrementally higher fields } \\
\text { (acquisition of IRM, i.e., aIRM) bring forth information on magnetic } \\
\text { mineralogy as a function of coercivity. Conventionally saturation } \\
\text { IRM (SIRM) designates the IRM produced in the highest field } \\
\text { adopted (1-2.5 Teslas). Magnitude of IRM is inversely dependent } \\
\text { on magnetite grain size. Measurement of a remanence induced in a } \\
\text { reversed direction after peak field (usually 10-20\% from peak field } \\
\text { strength) allows estimation of the easiness of remagnetization, which } \\
\text { is interpreted in terms of magnetic mineralogy or grain size. }\end{array}$ & $\begin{array}{l}\text { CR and LS: aIRM } \\
\text { measurements } \\
\text { performed using option } \\
\text { (1) with peak field } 2500 \\
\text { mT and back field } 200 \\
\text { mT } \\
\text { For CS: aIRM } \\
\text { measurements were } \\
\text { performed using option } \\
\text { (2) with peak field } 2000 \\
\text { mT and back field } 300 \\
\text { mT. }\end{array}$ \\
\hline \multicolumn{5}{|c|}{ Parameters related to determination of magnetic grain size } \\
\hline $\begin{array}{l}\text { - Saturation magnetization } \\
M_{\mathrm{S}} \\
\text { - Saturation remanent } \\
\text { magnetization } M_{\mathrm{sr}} \\
\text { - Coercive field } B_{\mathrm{c}}\end{array}$ & $\begin{array}{l}\text { Alternating field } \\
\text { magnetometer Micromag } \\
2900\end{array}$ & $\mathrm{Am}^{-1}$ & $\begin{array}{l}M_{\mathrm{S}} \text { is an in-field measure and describes magnetization in a } \\
\text { saturating field. } M_{\mathrm{sr}} \text { is the remanence left after switching off the } \\
\text { field. } B_{\mathrm{c}} \text { is an in-field measure and it states the field strength } \\
\text { required to bring magnetization to zero after saturation. In } \\
\text { particular, } B_{\mathrm{c}} \text { reflects magnetite grain size. Measurement of a } \\
\text { hysteresis loop allows the determination of } M_{\mathrm{S}}, M_{\mathrm{sr}} \text { and } B_{\mathrm{c}} \text {. }\end{array}$ & $\begin{array}{l}\text { Measured only from CS } \\
\text { and LS }\end{array}$ \\
\hline $\begin{array}{l}\text { - Coercivity of } \\
\text { remanence } B_{\mathrm{cr}}\end{array}$ & $\begin{array}{l}\text { Alternating field } \\
\text { magnetometer Micromag } \\
2900\end{array}$ & $\mathrm{mT}$ & $\begin{array}{l}B_{\mathrm{cr}} \text { expresses the magnetic field strength required to demagnetize } \\
M_{\mathrm{sr}} \text { to zero remanence. } B_{\mathrm{cr}} \text { reflects both magnetic mineralogy } \\
\text { and grain size. }\end{array}$ & $\begin{array}{l}\text { Measured only from CS } \\
\text { and LS }\end{array}$ \\
\hline \multicolumn{5}{|c|}{ Interparametric ratios } \\
\hline $\mathrm{SIRM} / \kappa_{\mathrm{lf}}$ & & $\mathrm{kA} \mathrm{m}^{-1}$ & $\begin{array}{l}\text { Sensitive to magnetic grain size in magnetite. Values vary } \\
\text { inversely with magnetic grain size. As essentially a concentration } \\
\text { dependent parameter, } \kappa_{\mathrm{lf}} \text { is used for normalizing the concentration } \\
\text { dependence of SIRM, leaving out information on grain size. }\end{array}$ & $\mathrm{CR}, \mathrm{CS}$ and $\mathrm{LS}$ \\
\hline$S$ ratio & & Unitless & $\begin{array}{l}\text { Ratio between two IRM measurements. Calculated here as } \\
0.5 \times[1-(\text { IRM@ highest field/IRM@ back-field)]. Allows estimation of } \\
\text { the easiness of remagnetization, which relates to magnetic } \\
\text { mineralogy. Commonly interpreted as the ratio between magnetite } \\
\text { and hematite in a sample, where value } 1(0) \text { designates the only } \\
\text { magnetic mineral present is magnetite (hematite). }\end{array}$ & $\mathrm{CR}, \mathrm{CS}$ and $\mathrm{LS}$ \\
\hline$M_{\mathrm{s}} / M_{\mathrm{sr}}$ & & Unitless & $\begin{array}{l}\text { The ratio } M_{\mathrm{S}} / M_{\mathrm{sr}} \text { is inversely related to magnetite grain size. This } \\
\text { ratio is used as a part of a Day plot to characterize the magnetite domain } \\
\text { state. }\end{array}$ & CS and LS \\
\hline$B_{\mathrm{c}} / B_{\mathrm{cr}}$ & & Unitless & $\begin{array}{l}\text { The ratio } B_{\mathrm{c}} / B_{\mathrm{cr}} \text { is directly proportional to magnetite grain size. } \\
\text { This ratio is used as a part of a Day plot to characterize the magnetite } \\
\text { domain state. }\end{array}$ & CS and LS \\
\hline
\end{tabular}

Therefore investigation of the core catcher samples from Site 5011-1 offers a possibility to acquire mineral magnetic information in low resolution throughout the $315 \mathrm{~m}$-long sequence. One sample was taken from each core catcher sediment sample by pressing a paleomagnetic sample box (volume $6 \mathrm{~cm}^{3}$ ) into the upper surface of the sediment block. Selected magnetic parameters were determined in order to estimate the concentration, mineralogy and magnetic grain size range of magnetic minerals in these samples $(n=122)$. These parameters, which include low-field volume magnetic susceptibility $\left(\kappa_{\mathrm{lf}}, \mathrm{SI} \times 10^{-6}\right)$, isothermal remanent magnetization (IRM) with different applied field strengths and magnetic hysteresis parameters $\left(M_{\mathrm{s}}, M_{\mathrm{rs}}, B_{\mathrm{c}}\right.$ and $\left.B_{\mathrm{cr}}\right)$, are listed together with their description and information on the instrumentation in Table 2. More information on mineral magnetic parameters and their interpretation can be found in, e.g., Thompson and Oldfield (1986). After finalizing the magnetic measurements on bulk samples, samples were freeze-dried and gently ground with an agate mortar and pestle. Sub-samples for magnetic hysteresis measurements were prepared by mixing ground sediment with a droplet of instant glue and forming $3 \times 3 \mathrm{~mm}$ pellets $(n=122)$ for analysis. 


\subsection{Mineral magnetic measurements on catchment rocks and creek sediments}

Besides the lacustrine sediments, catchment rocks and sediments collected from creeks, which drain the catchment, were investigated in order to collect information on the source and origin of magnetic minerals in the sediments deposited in Lake El'gygytgyn. Rock samples were collected from the catchment during an expedition to the lake in spring 2003 (Melles et al., 2005). These samples were available for screening of mineral magnetic properties of the source rocks. Distribution of the analyzed rock samples within the catchment is not uniform, but approximately two thirds of the collected rock samples are from the area extending from east to southwest of the lake, and the remaining third originates from an area northwest of the lake (Fig. 1). The uneven distribution of collected samples, which results from the lack of suitable outcrops, introduces a spatial bias, but preliminary apprehension of the magnetic properties of the catchment rocks, appropriate for the purposes of this study, is acquired. Part of the rock samples $(n=23)$ were taken as oriented hand samples directly from available bedrock outcrops, whereas most of the samples were collected from periglacial colluvium $(n=58)$ from the base of slopes surrounding the lake. Where necessary, these two sample types are jointly referred to as catchment rock samples. Cylinder-shaped mini-sized specimens $\left(n=80\right.$; mean diameter $12 \mathrm{~mm}$, volume $\left.2.0 \mathrm{~cm}^{3}\right)$ were drilled from the catchment rock samples. Low-field magnetic volume susceptibility, acquisition of isothermal remanent magnetization (IRM) and $S$ ratio were measured from the catchment rocks in a fashion identical to lake sediment samples (Table 2). Magnetic hysteresis measurements were not performed on catchment rock samples. Bulk sediment samples from bedload of creeks and shallow lagoons, blocked by coarse sand bars in the mouth of creeks, were collected during the same expedition as the catchment rocks in 2003. From now on, these sediments are jointly referred here to as creek sediments. Creek sediments from 32 sites, distributed evenly across the lake circumference, were packed tightly into paleomagnetic sample boxes $\left(6 \mathrm{~cm}^{3}\right)$ and stabilized by epoxy resin for measurements of mineral magnetic properties. In Table 2 more information is provided on magnetic measurements performed on creek sediments.

\subsection{SEM-EDS analysis of magnetic separates from creek sediments}

In order to investigate mineralogy and visual characteristics of magnetic grains in more detail, magnetic minerals were investigated from polished rock sections and magnetic separates extracted from creek sediments. Magnetic minerals were manually separated from selected air-dried creek sediment samples using a rare earth magnet. Sub-samples taken from these magnetic separates were mounted on a standard SEM stubs and sputtered with carbon for inspection with a

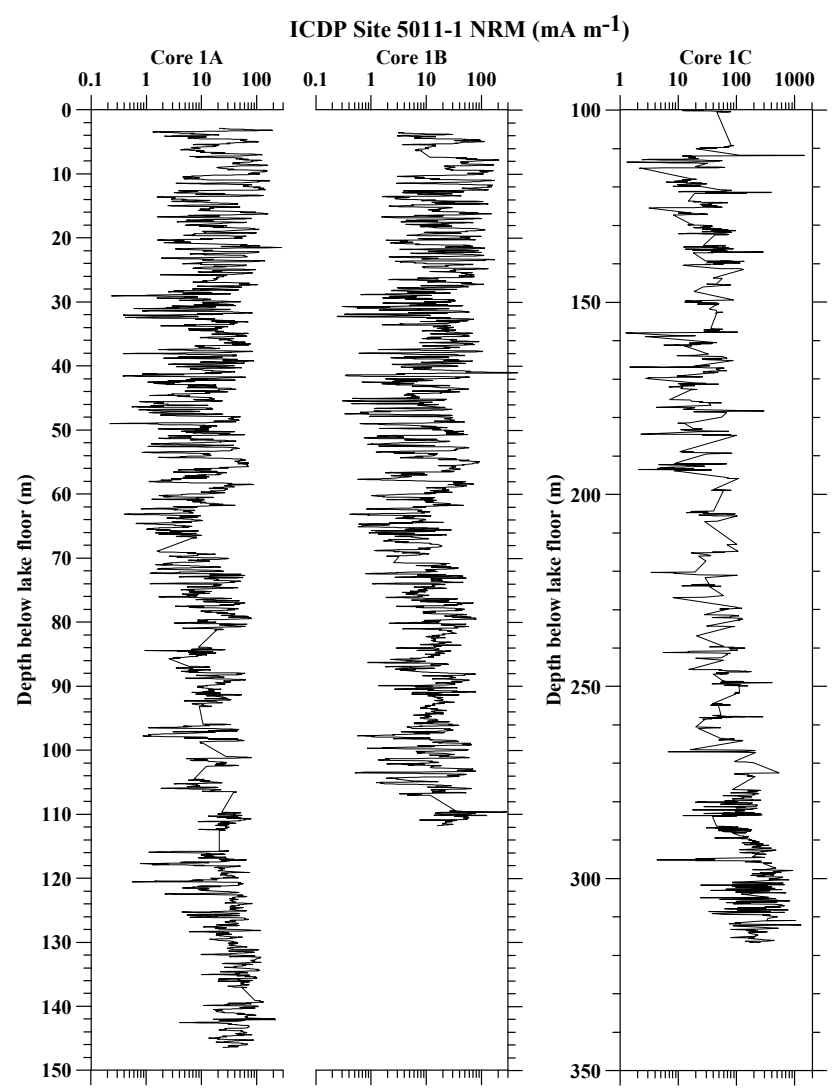

Fig. 2. Down-core variations in the intensity of the natural remanent magnetization (NRM) in cores $1 \mathrm{~A}, 1 \mathrm{~B}$ and $1 \mathrm{C}$. Note the different scaling in $1 \mathrm{C}$.

scanning electron microscopy (SEM), equipped with an energy dispersive X-ray spectroscopy facility (EDS), using a Zeiss Ultra 55 Plus microscope. The instrument permits elemental analyses of the separated magnetic minerals and detailed observation of grain morphology. Magnetic minerals present in rocks were investigated from polished sections ( $n=19$, thickness $0.5 \mathrm{~mm}$ ), which were prepared from the mini-sized specimens. The polished sections were mounted on glass slides, coated with carbon and analyzed with the SEM-EDS.

\section{Results and interpretation}

\subsection{Polarity stratigraphy from cores $1 \mathrm{~A}$ and $1 \mathrm{~B}$}

NRM intensity is high, with a range of values mainly between 1 and $100 \mathrm{mAm}^{-1}$ (Fig. 2). The sediments mostly display stable magnetization, which displays linear decay on orthogonal vector plots during progressive demagnetization. However, some samples showed two or more components of magnetization, and stable direction of magnetization was isolated after removal of the low-coercivity fraction at $\mathrm{AF}$ demagnetization of $15 \mathrm{mT}$ (Fig. 3). The interval 

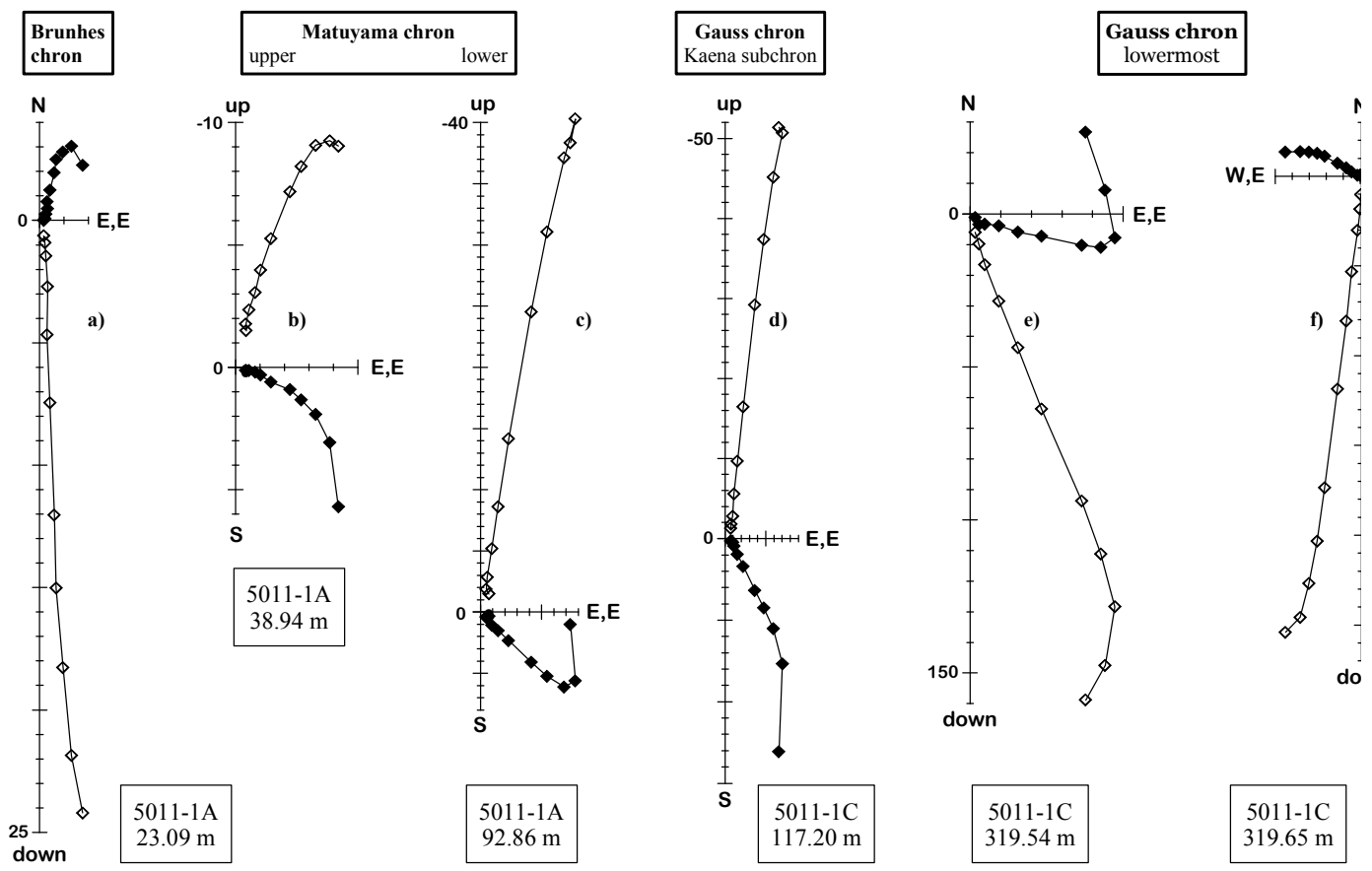

Fig. 3. Representative vector endpoint diagrams obtained from progressive alternating field demagnetization of natural remanent magnetization of sediments from cores 1A (a-c) and 1C (d-f) from Lake El'gygytgyn. Samples show high directional stability. Solid (open) diamonds indicate projection to the horizontal (vertical) plane. Axes are individually scaled from graph to graph with units in $\mathrm{mA} \mathrm{m}^{-1}$.

most often applied in the determination of ChRM was that from 15 to $65 \mathrm{mT}$. The magnetization is mainly carried by magnetic minerals with a low coercivity, and usually $\leq 5 \%$ of the NRM remains after completion of the AF magnetic cleaning at $100 \mathrm{mT}$ (Fig. 4). However, in a few cases, contribution from high-coercivity mineral(s) was evident, with $50 \%$ of the NRM remaining after applying the peak demagnetizing field. In most cases the MAD angle is $<5^{\circ}$, which indicates that a well-defined magnetization vector was isolated during principal component analysis. Larger MAD angles are usually found in samples, which show weak magnetization. These are generally associated with polarity transitions. Few samples, which show multiple components of magnetization, are characterized by weak NRM intensity and significant contribution of magnetically harder minerals. Only the inclination of the ChRM will be used to determine magnetic polarity, because the sediment sections were oriented with respect to their $z$ axis, but the azimuth angle is unknown. Inspection of ChRM inclination records from cores $1 \mathrm{~A}$ and $1 \mathrm{~B}$ revealed similar patterns of sediment intervals, which have mostly steep inclination with either normal or reversed polarity (Figs. 5 and 6), and normal polarity inclinations oscillate around the expected axial dipole inclination value of $78.3^{\circ}$ for the site. The reconstructed patterns of ChRM inclination from cores $1 \mathrm{~A}$ and $1 \mathrm{~B}$ can be readily correlated with the established pattern of magnetic field reversals during the last 2.6 Myr (Ogg and Smith, 2004), and polarity reversals in cores $1 \mathrm{~A}$ and $1 \mathrm{~B}$, proceeding from

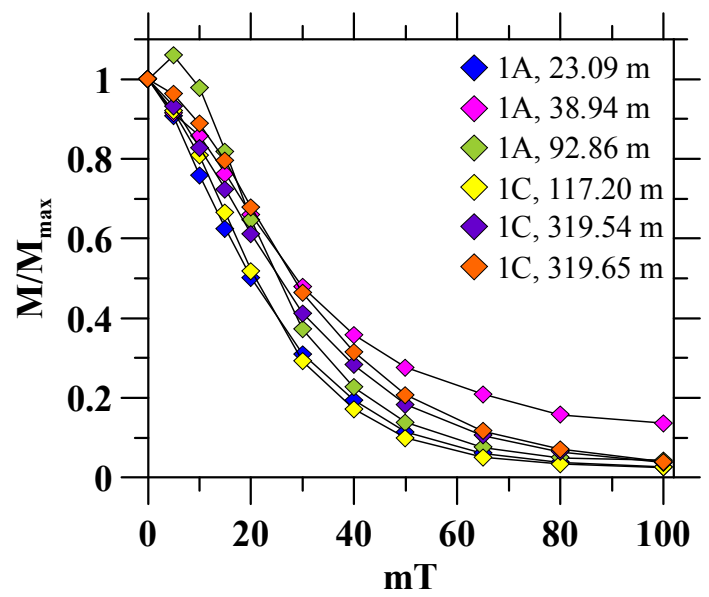

Fig. 4. Curves of normalized NRM intensity versus peak alternating field demagnetization steps from 0 to $100 \mathrm{mT}$. Samples are the same as in Fig. 3. Smoothly reducing remanence is indicative of lowcoercivity magnetic components dominating the remanence in these samples.

top to down, are interpreted as follows. The polarity is nor$\mathrm{mal}$ in the uppermost $28.5 \mathrm{~m}$, and this interval is interpreted as the Brunhes chron. Polarity change at $28 \mathrm{~m}$ is correlated with the $\mathrm{B} / \mathrm{M}$ boundary at $0.780 \mathrm{Ma}$. In two sediment intervals polarity is consistently normal within the Matuyama chron. These sections extend from 38 to $40.5 \mathrm{~m}$ and from 


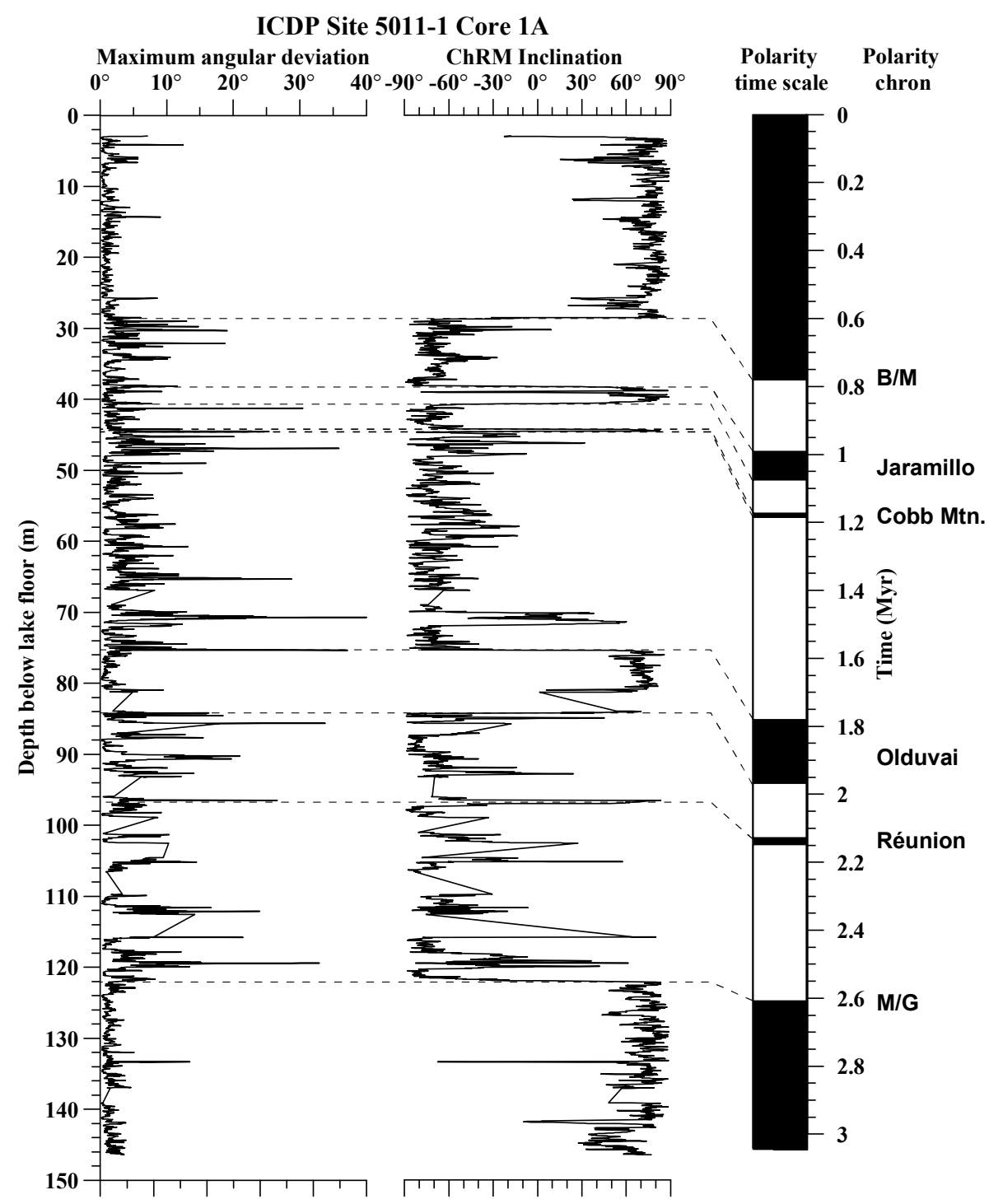

Fig. 5. Down-core variations in the inclinations of the characteristic remanent magnetization (ChRM) and maximum angular deviation (MAD) from core 1A. Dashed lines denote correlation of the ChRM inclination with the polarity timescale.

75 to $84 \mathrm{~m}$, and they are interpreted as the Jaramillo subchron (1.075 to $0.991 \mathrm{Ma}$ ) and the Olduvai subchron (from 1.968 to $1.781 \mathrm{Ma}$ ), respectively. The sediments from the early Olduvai were recovered only in core $1 \mathrm{~B}$ and characterized by a scattered ChRM inclination pattern. Here data are partly ambiguous because of folding structures in the sediment strata, which renders polarity reconstruction complex in this part of the sediment sequence. Unfortunately, a core break occurs at $122 \mathrm{~m}$ in core $1 \mathrm{~A}$ as polarity shifts from normal to reversed. This depth approximates the $\mathrm{M} / \mathrm{G}$ reversal, which occurred at $2.608 \mathrm{Ma}$. In some sediment sections, such as in a notable example from 70 to $72 \mathrm{~m}$ in core $1 \mathrm{~A}, \mathrm{ChRM}$ inclinations are shallow and without a counterpart in the parallel core. These represent either sediment disturbances such as folding structures where paleomagnetic direction does not reflect primary orientation, or coarse-grained bases of mass movement deposits, where paleomagnetic direction can be poorly recorded. These are not taken as reflections of past geomagnetic field configurations.

After identification of three polarity chrons and two subchrons in the uppermost $146 \mathrm{~m}$ of sediment, two polarity subchrons can be identified in the Matuyama chron in both cores $1 \mathrm{~A}$ and 1B. These are centered at 44 and $97 \mathrm{~m}$, and they are interpreted as the Cobb Mountain cryptochron (Mankinen et al., 1978) (1.185 to $1.173 \mathrm{Ma}$ ) and the Réunion subchron (Chamalaun and McDougall, 1966) (from 2.148 to $2.128 \mathrm{Ma}$ ), respectively (ages from Ogg and Smith, 2004). Interestingly, both cores recorded a short interval of fully reversed polarity during the late Jaramillo subchron at $39 \mathrm{~m}$, possibly correlative to the Intra-Jaramillo excursion, which 


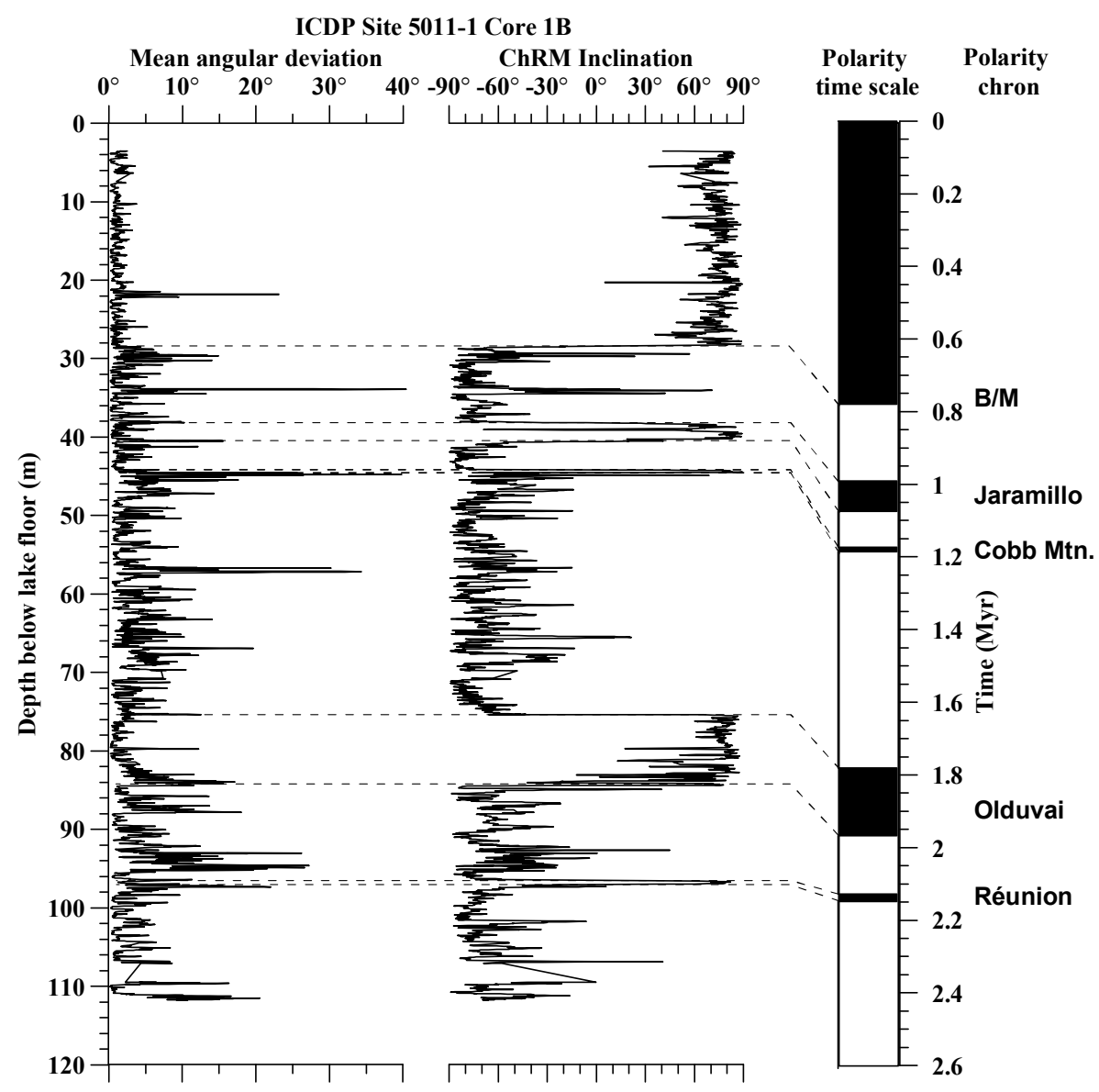

Fig. 6. Down-core variations in the inclinations of the characteristic remanent magnetization (ChRM) and maximum angular deviation (MAD) from core 1B. Dashed lines denote correlation of the ChRM inclination with the polarity timescale.

has been suggested to represent a short global geomagnetic event (Pillans et al., 1994; Channell and Kleiven, 2000; Guo et al., 2002). Another possible short geomagnetic event is detected at the depth of $\sim 85 \mathrm{~m}$ in both cores, with a "flip" to full normal polarity just before the onset of the Olduvai subchron, which may represent the Olduvai precursor (Channell et al., 2003). As a result of astronomical tuning of different paleoenvironmental proxies, Nowaczyk et al. (2013) provide ages for the onset and termination of these short-lived geomagnetic features. The Intra-Jaramillo excursion occurred from 1.0192 to $1.0142 \mathrm{Ma}$ and is therefore placed in MIS (Marine Isotope Stage) 29. This age is slightly younger than that given by Channell et al. (2002), who place it in MIS 30 . The tuning-based age model brackets the age for the Olduvai precursor between 1.9815 and $1.9782 \mathrm{Ma}$, which is in line with the age of the event found in North Atlantic sediments (1.977 Ma) (Channell et al., 2003).

\subsection{Polarity stratigraphy of core 1C}

The NRM intensity in core $1 \mathrm{C}$ is high, with a range mainly between 10 and $1000 \mathrm{~mA} \mathrm{~m}^{-1}$ (Fig. 2). Highest NRM values are found in the bottommost sediments of the core from 298 to $315 \mathrm{~m}$. In general, the sediments display a stable magnetization during $\mathrm{AF}$ demagnetization, as was the case in cores $1 \mathrm{~A}$ and $1 \mathrm{~B}$ (Fig. 3). Inspecting the reconstructed ChRM inclination record from core 1C (Fig. 7) in context with the paleomagnetic record from core 1A (Fig. 5), the shift from reversed to normal polarity at $121.5 \mathrm{~m}$ can be assigned as the $\mathrm{M} / \mathrm{G}$ boundary, which coincided with a core break in core 1A. A more scattered ChRM inclination record with normal and reversed polarity arises from the sediments between 145 and $290 \mathrm{~m}$, or between 2.95 and 3.55 Ma. This part of the sediment sequence is characterized by higher sand and gravel content in comparison with younger sediments. Sediments between 158 and $161.5 \mathrm{~m}$ show mainly reversed polarity, and this interval is interpreted as representing the Kaena subchron (3.127 to 3.045 Ma). Due to the low quality of data and missing sediment, termination of the Kaena remains vaguely determined in the paleomagnetic record. Consequently this tie point is not considered as first-order. Below the Kaena, ChRM inclinations mainly have a normal polarity. Between 169.6 and $193.8 \mathrm{~m}$ sediments again display an interval with somewhat scattered polarities, but the polarity tends 


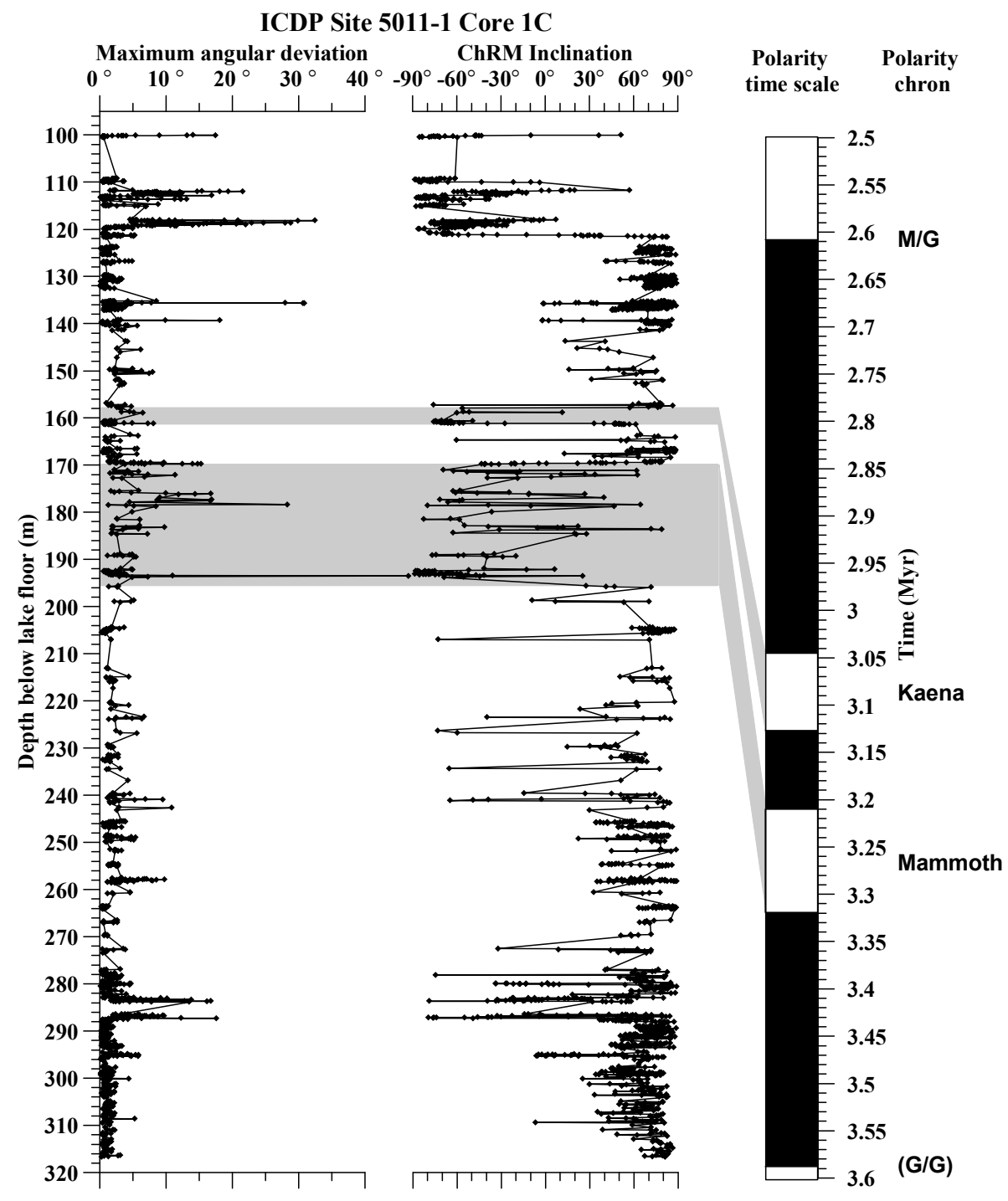

Fig. 7. Down-core variations in the inclinations of the characteristic remanent magnetization (ChRM) and maximum angular deviation (MAD) from core 1C. Shaded areas denote correlation of the ChRM inclination with the polarity timescale. Gauss/Gilbert (G/G) boundary at $3.588 \mathrm{Ma}$ is not recorded by the sediments.

to stay more in reversed than normal mode. These sediments are therefore interpreted as having been deposited during the Mammoth subchron (3.319 to 3.210 Ma). Unfortunately, there is a gap in sediment recovery directly below $193.8 \mathrm{~m}$. Directly below this gap, the polarity is predominantly normal and represents the Gauss chron. As a consequence, the onset of Mammoth cannot be precisely determined from the paleomagnetic data alone, and this tie point is ranked secondary. Sediment intervals extending from 224 to $241.5 \mathrm{~m}$ and especially that from 280 to $286.5 \mathrm{~m}$ show several data points with reversed polarity sandwiched between those correlated with the early normal polarity Gauss. These cannot be correlated with any known and widely accepted geomagnetic polarity events or excursions. The deeper parts of the sediment record ( $\geq 287 \mathrm{~m}$ ) show continuously a normal polarity.
These sediments can be interpreted as having been deposited during the early Gauss chron, bearing in mind that the crater was formed at $3.58 \pm 0.04 \mathrm{Ma}$ (Layer, 2000), shortly after the Gauss/Gilbert (G/G) reversal (3.588 Ma).

\subsection{Carrier of remanence in lake sediments and its origin}

SEM-EDS microanalyses of polished sections of catchment rocks revealed the ubiquitous presence of large multi-domain (MD) sized grains of titanium-substituted magnetite (Timagnetite or titanomagnetite, $\mathrm{Fe}_{3-\mathrm{x}} \mathrm{Ti}_{\mathrm{x}} \mathrm{O}_{4}$ ), mainly between 10 and $100 \mu \mathrm{m}$ in size (Fig. 8a). In many samples the titanomagnetite grains are either uniformly finely fractured with irregular curved cracks, or alternatively they have a 

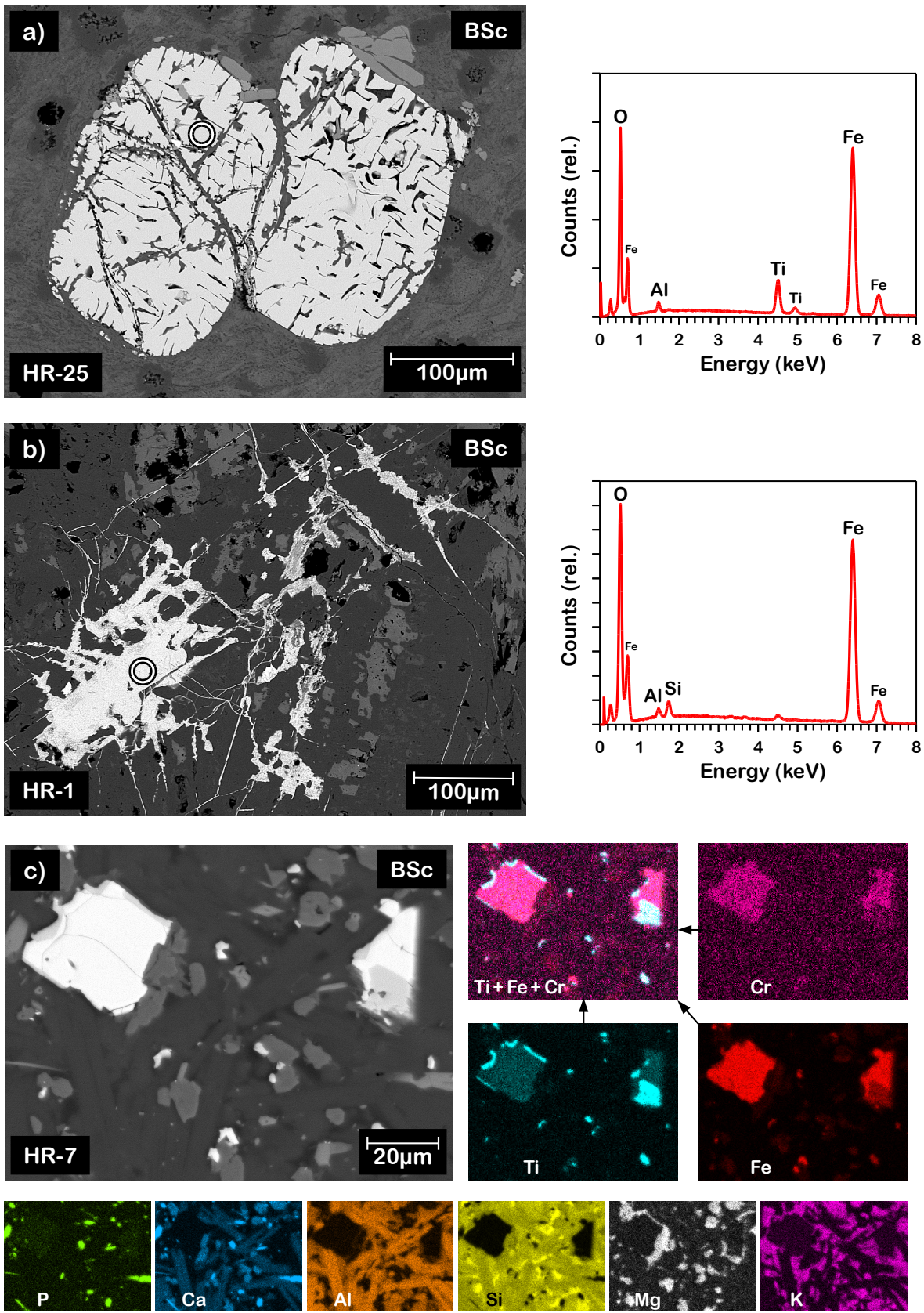

Fig. 8. Scanning electron microscope (SEM) analyses of polished sections from selected catchment rock samples: (a) SEM image and EDS analysis of a large titanomagnetite grain, $\mathrm{Fe}_{3-\mathrm{x}} \mathrm{Ti}_{\mathrm{x}} \mathrm{O}_{4}(0 \leq x \leq 1)$, in a rhyolitic sample from the distal southeastern catchment. Visible (shrinkage) cracks might be due to in situ low-temperature oxidation (maghemitization). (b) SEM image and EDS analysis of an iron oxide, probably hematite, in a rhyolitic sample from the eastern shoreline, (c) SEM image and corresponding elemental mapping of major elements in a basaltic-andesitic sample from the distal eastern catchment. The sample shows in superimposed $\mathrm{Fe}$, Ti, and $\mathrm{Cr}$ mapping intergrowth of titanomagnetite and Cr-bearing magnetite, $\mathrm{FeFe}_{(2-\mathrm{x})} \mathrm{Cr}_{\mathrm{x}} \mathrm{O}_{4}(0 \leq x \leq 2)$. Bright patches both in the $\mathrm{P}$ and Ca mappings point to the presence of apatite, $\mathrm{Ca}_{5}\left(\mathrm{PO}_{4}\right)_{3}(\mathrm{Cl}, \mathrm{F}, \mathrm{OH})$, whereas mappings of $\mathrm{Ca}, \mathrm{Al}, \mathrm{Si}, \mathrm{Mg}$, and $\mathrm{K}$ together reflect the distributions of various silicates. The circles in (a) and (b) mark the locations of EDS analyses. EDS - energy dispersive X-ray spectroscopy, BSc - back scatter electrons. 
Table 3. Selected magnetic parameters from catchment rocks, creek sediments and lake sediments. Mean value, (standard deviation) and [total range of values] are shown. See text for discussion.

\begin{tabular}{llllll}
\hline Investigated material & Parameter/ratio & & & & \\
& $\kappa_{\text {lf }}\left(\mathrm{SI} \mathrm{10} 0^{-6}\right)$ & SIRM $\left(\mathrm{A} \mathrm{m}^{-1}\right)$ & $S$ ratio & SIRM/ $\kappa_{\mathrm{lf}}\left(\mathrm{kA} \mathrm{m}^{-1}\right)$ & $B_{\mathrm{cr}}(\mathrm{mT})$ \\
Catchment rocks & & & & & \\
- Bedrock & $10749(10238)$ & $105.28(69.73)$ & $0.95(0.05)$ & $23.49(25.85)$ & $\mathrm{n} / \mathrm{a}$ \\
& {$[365.26-30960]$} & {$[5.31-252.17]$} & {$[0.79-0.99]$} & {$[1.85-80.57]$} & \\
- Colluvium & $9498.0(9874.5)$ & $157.55(144.50)$ & $0.92(0.15)$ & $25.00(20.40)$ & $\mathrm{n} / \mathrm{a}$ \\
& {$[62.49-49026]$} & {$[1.29-843.50]$} & {$[0.46-1.00]$} & {$[0.69-98.46]$} & \\
Creek sediments & $3072.6(1661.5)$ & $20.27(7.12)$ & $0.98(0.01)$ & $7.30(2.19)$ & $32.28(8.86)$ \\
& {$[1516.5-7906.7]$} & {$[10.62-41.29]$} & {$[0.96-0.99]$} & {$[3.76-12.81]$} & {$[20.27-50.09]$} \\
Lake sediments & $2557.7(2630.0)$ & $18.17(15.61)$ & $0.98(0.05)$ & $7.42(1.80)$ & $23.40(4.99)$ \\
& {$[124.60-17590]$} & {$[0.43-75.16]$} & {$[0.57-0.99]$} & {$[2.05-13.21]$} & {$[18.60-44.57]$} \\
\hline
\end{tabular}

rim of fractures surrounding an apparently unaltered center. This fracturing is presumably caused by gradual lowtemperature oxidation of titanomagnetites, which results in outward migration of $\mathrm{Fe}$ cations and relative enrichment of Ti cations. This alteration process affecting magnetic properties is called maghemitization, which has been described from titanomagnetites in volcanic rocks in different geological settings (Marshall and Cox, 1972; Akimoto et al., 1984; Cui et al., 1994; Nowaczyk, 2011). Besides maghemite $\left(\gamma-\mathrm{Fe}_{2} \mathrm{O}_{3}\right.$, with a cation-deficient spinel structure), magnetite $\left(\mathrm{Fe}_{3} \mathrm{O}_{4}\right)$ and spinels from the magnetite-chromite solid solution series $\left(\mathrm{Fe}\left(\mathrm{Fe}_{\mathrm{x}} \mathrm{Cr}_{2-\mathrm{x}}\right) \mathrm{O}_{4} ; 0 \leq x \leq 2\right)$ were detected. Hematite $\left(\alpha-\mathrm{Fe}_{2} \mathrm{O}_{3}\right.$, with a corundum structure) often occurs as narrow irregular veins, which fill in the spaces between other mineral crystals, or alternatively, as fine-grained inclusions in other minerals (Fig. 8b). In many cases, magnetite grains in the catchment of Lake El'gygytgyn are associated with apatite intergrowths $\left(\mathrm{Ca}_{5}\left(\mathrm{PO}_{4}\right)_{3}(\mathrm{~F}, \mathrm{Cl}, \mathrm{OH})\right)$ (Fig. 8b and c).

In line with the results from polished rock sections, SEMEDS analysis of magnetic separates from creek sediments revealed titanomagnetite grains of a large MD size range (Fig. 9a). Similar to source rocks, many of the titanomagnetite grains are cracked due to low-temperature oxidation of magnetic minerals. While some grains have notably rounded edges probably due to abrasion while being transported in creek bedload, many particles are characterized by an idiomorphic shape, or by sharp crystal edges, which indicates only short-distance transport from their source (Fig. 9a-e). Considering the small size of the Lake El'gygytgyn catchment, sediment transport distances in creeks discharging into the lake can be expected to be short. While aeolian flux today comprises only a small part (2\%) of total sediment income in Lake El'gygytgyn (Fedorov et al., 2013), its role in transporting ferrimagnetic particles may have been more important during Pleistocene glaciations (Maher, 2011).
In accordance with results from microanalyses, results from mineral magnetic measurements suggest the dominance of low-coercivity minerals in the magnetic properties of catchment rocks, creek sediments and lake sediments. Results from the magnetic measurements including $\kappa_{\mathrm{lf}}$, SIRM, $S$ ratio, SIRM/ $\kappa_{\mathrm{lf}}$ and $B_{\mathrm{cr}}$, are summarized in Table 3. Stepwise acquisition of IRM indicates that the majority of catchment rock samples and creek sediments acquired $90 \%$ of their SIRM after application of a magnetic field of $\leq 200 \mathrm{mT}$ (Fig. 10). Rapid acquisition of remanence in low magnetic fields $(<50 \mathrm{mT})$ supports the interpretation of a low-coercivity magnetic component, such as MD-sized titanomagnetite, as the dominating magnetic mineral in catchment rocks. High $S$ ratios measured from catchment rocks and creek sediments point out again that titanomagnetite is dominating their magnetic properties (Table 3). Concentration of magnetic minerals in catchment rocks, as estimated by SIRM and $\kappa_{\mathrm{lf}}$, is comparable to that generally found in igneous rocks (Hunt et al., 1995). Expressed in terms of mass percentage using an average value of mass-specific susceptibility for titanomagnetite of $422 \mathrm{~m}^{3} \mathrm{~kg}^{-1}\left(\mathrm{SI} \times 10^{-6}\right)$ (Peters and Dekkers, 2003), the mean concentration of titanomagnetite in the source rocks can be estimated as $0.96 \%$, with a range from 0.01 to $4.15 \%$. The variable lithology and the variable degree of physical and chemical alteration of the investigated source rocks is reflected in the highly variable concentration of magnetic minerals in the analyzed rock samples, and it can be characterized by $\kappa_{\mathrm{lf}}$ vs. a SIRM bi-plot, which visualizes variations in the mineralogy, concentration, and grain size of magnetic minerals (Fig. 11). Colluvial rock samples yield higher but less clustered SIRM values (Table 3) in comparison with those samples drilled directly from bedrock. This is tentatively interpreted to reflect a higher degree of maghemitization of titanomagnetites in colluvium due to increased fracturing as a result of having been exposed more extensively to physical and chemical weathering. 

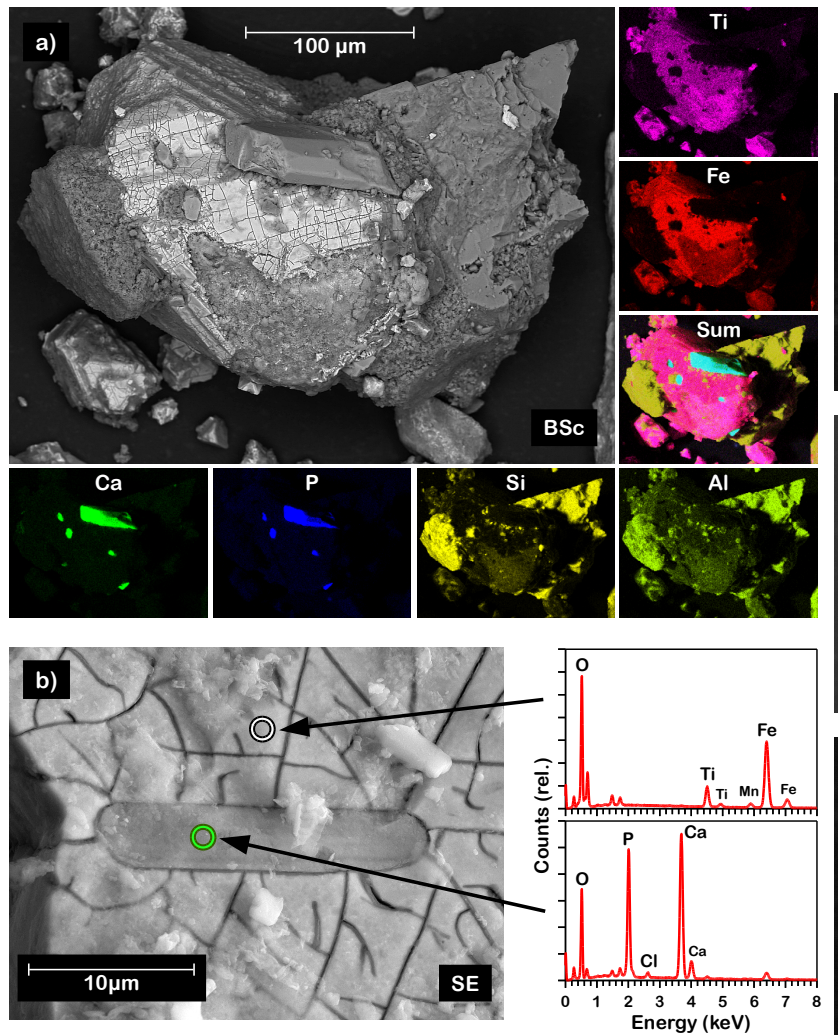
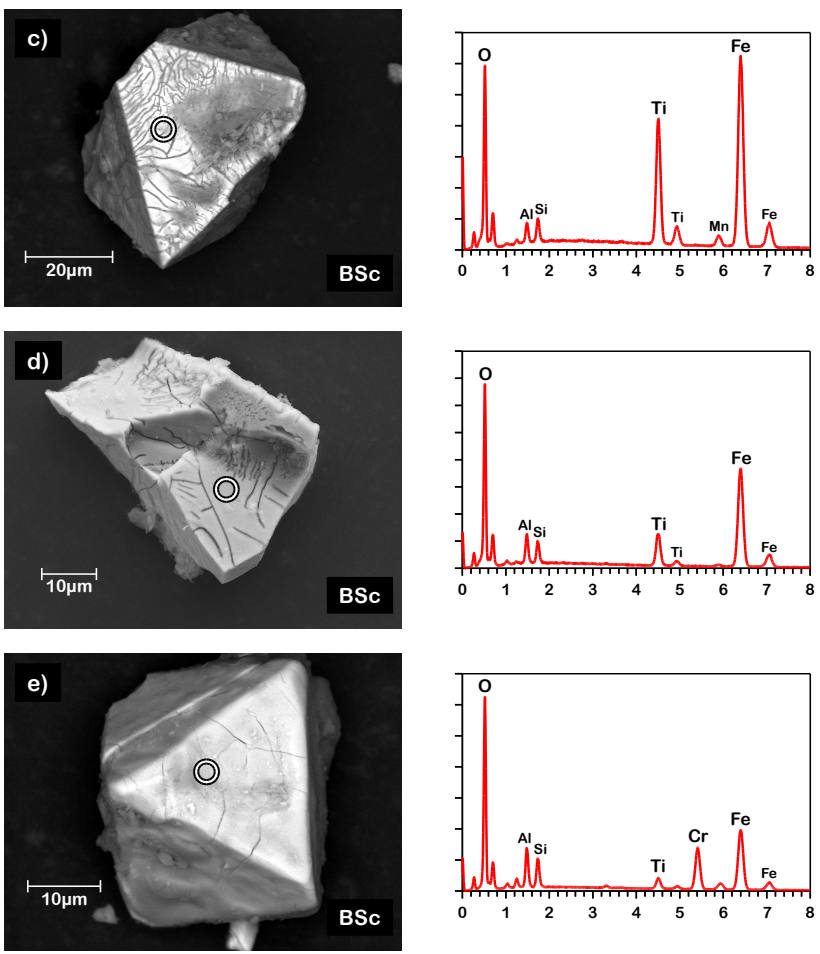

Fig. 9. Scanning electron microscope (SEM) analyses of magnetic extracts from creek sediments from the northwestern shore of El'gygytgyn: (a) SEM image and elemental mapping of a large $\left(\sim 400\right.$ mum) titanomagnetite grain, $\mathrm{Fe}_{3-\mathrm{x}} \mathrm{Ti}_{\mathrm{x}} \mathrm{O}_{4}(0 \leq x \leq 1)$, represented by the Fe and $\mathrm{Ti}$ mappings. The titanomagnetite is still encrusted by minerals of the host rock, where bright patches in the $\mathrm{P}$ and Ca mapping indicate the presence of apatite, $\mathrm{Ca}_{5}\left(\mathrm{PO}_{4}\right)_{3}(\mathrm{Cl}, \mathrm{F}, \mathrm{OH})$, whereas mappings of $\mathrm{Al}$ and $\mathrm{Si}$ reflect the distributions of silicates. (b) A close-up of another titanomagnetite with apatite inclusion, together with associated EDS analyses. (c) Idiomorphic and (d) irregular titanomagnetite grain. (e) Idiomorphic Cr-bearing magnetite, $\mathrm{FeFe}_{(2-\mathrm{x})} \mathrm{Cr}_{\mathrm{X}} \mathrm{O}_{4}(0 \leq x \leq 2)$. More or less distinctively visible shrinkage cracks in all grains indicate low-temperature oxidation (maghemitization). The circles from (b) to (e) mark the locations of EDS analyses. EDS - energy dispersive X-ray spectroscopy, BSc - back scatter electrons, SE - secondary electrons.

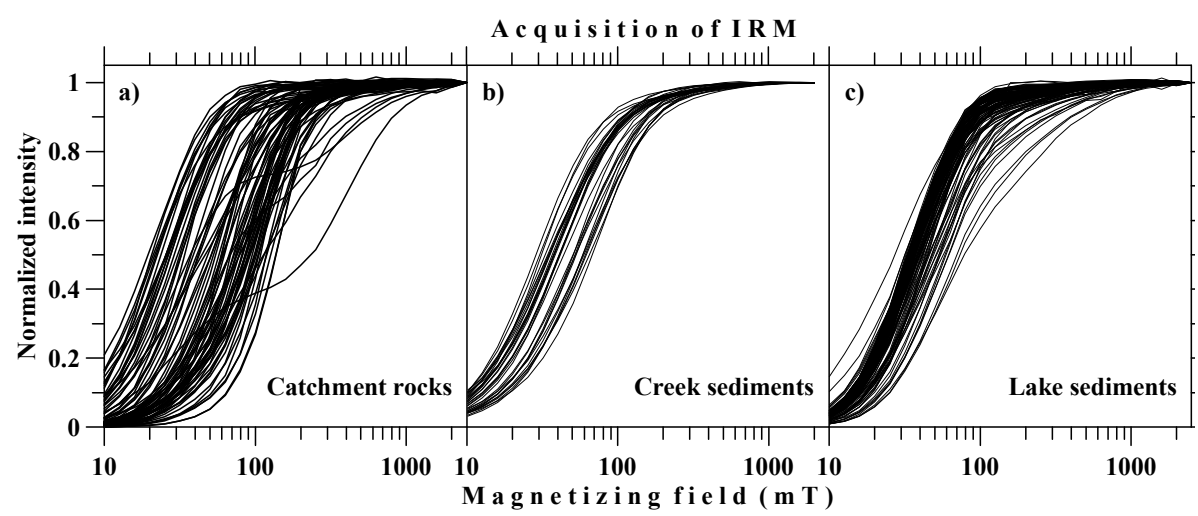

Fig. 10. Normalized acquisition of isothermal remanent magnetization (IRM) with respect to applied magnetic field strength in different sample types. (a) Catchment rocks gain remanence rapidly in low fields, indicating the presence of multi-domain titanomagnetite. (b) Creek sediments appear more homogenous in their grain size and mineralogy, and most samples are saturated by magnetic field $200 \mathrm{mT}$ in strength, which is typical of (titano)magnetite. (c) Similar to catchment rocks, some lake sediment samples indicate the presence of highcoercivity magnetic minerals. Most of the samples are dominated by low-coercivity titanomagnetite, as demonstrated by (near) saturation in fields $<200 \mathrm{mT}$. 


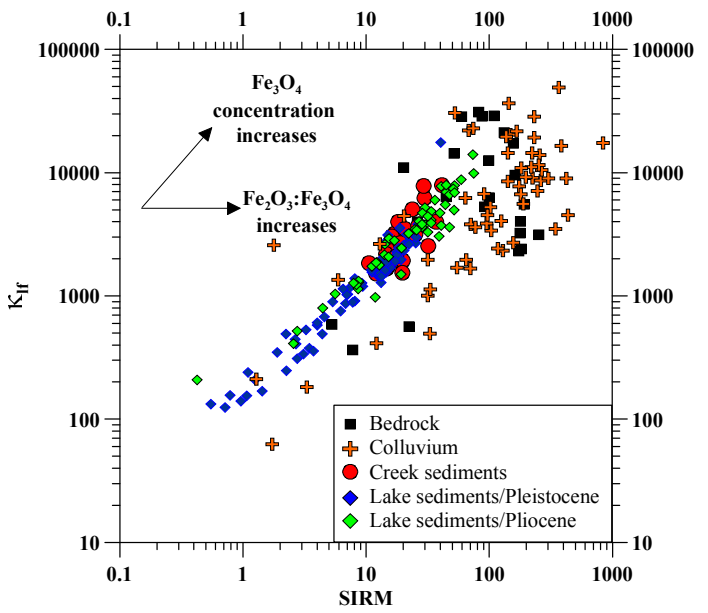

Fig. 11. Biplot of magnetic susceptibility $\left(\kappa_{\mathrm{lf}}\right)$ versus saturation remanent magnetization (SIRM). Deviations from a linear relationship between the two parameters in different sample types indicate variation in the proportions of the constituting magnetic minerals in rock/sediment magnetic assemblages. Catchment rocks, including colluvium and bedrock, show widely varying magnetic properties, whereas data from creek sediments are notably clustered. In contrast to catchment rocks, lake sediments indicate a linear relationship between the two magnetic parameters. This suggests a homogenous magnetic assemblage in the sediment column.

Hematite appears to be absent in creek sediments and consequently the magnetic mineralogy seems to be more uniform in comparison to catchment rocks. Hysteresis properties presented in a Day plot (Day et al., 1977) show that the magnetic grain size of creek sediments lies in the region, which represents the coarser end of the PSD range (Fig. 12). This is not directly in line with the observation of large MD titanomagnetite grains witnessed in SEM imaging. This could be caused by alteration of magnetic properties due to maghemitization and the associated shrinkage cracks, dividing large grains at least superficially, if not internally, into smaller domains (Cui et al., 1994). It is also possible that the rather crude method of magnetic extraction for SEM/EDS microscopy may not produce a representative sample of the magnetic assemblage present in creek sediments. Creek sediments have a lower concentration of magnetic minerals than catchment rocks (Table 3) and they appear notably clustered in the SIRM vs. $\kappa_{\text {lf }}$ bi-plot, but their magnetic mineralogy and grain size are largely homogenous. Interestingly, magnetic grain size, as deduced from the ratio $\operatorname{SIRM} / \kappa_{\mathrm{lf}}$, appears larger in creek sediments than in catchment rocks. It is possible that the ratio does not respond sensitively to magnetic grain size in this case, where magnetic mineralogy is characterized by maghemitized titanomagnetites. In their review aiming to define room-temperature magnetic parameters, which would best characterize different iron oxides and iron sulfides, Peters and Dekkers (2003) showed that $\kappa_{\text {lf }}$ and SIRM values of maghemite are largely independent of grain

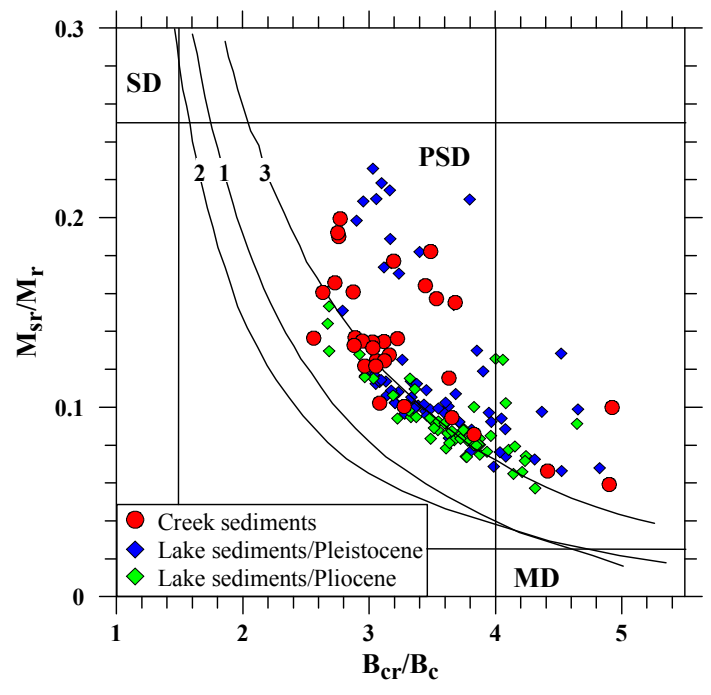

Fig. 12. Modified Day plot (Day et al., 1977) of magnetic hysteresis data obtained from material from Lake El'gygytgyn and its catchment. Symbols refer to the same material as listed in Fig. 11. Experimental mixing lines 1 and 2 refer to Dunlop (2002), and line 3 refers to work by Parry (1980). SD = single-domain, $\mathrm{PSD}=$ pseudosingle domain, $\mathrm{MD}=$ multidomain. Ratios calculated using data from hysteresis analyses and measurement of coercivity of remanence are indicative of magnetic domain status in titanomagnetite. The majority of the samples plot near mixing line 3, which suggests a PSD to MD domain state of the analyzed samples. In particular, Pleistocene age lake sediment samples and creek sediments plot to the right from the theoretical mixing lines. This is probably due to the contribution of hematite in the mineral magnetic assemblages.

size from PSD $(\sim 1-2 \mu \mathrm{m})$ to large MD $(\sim 200 \mu \mathrm{m})$, which explains, in this case, the insensitivity of the ratio SIRM $/ \kappa_{\mathrm{lf}}$ to magnetic grain size variations. Lake sediments acquire IRM in a manner similar to creek sediments (Fig. 10). However, approximately a quarter of samples show a more pronounced contribution from magnetic minerals with harder coercivity, most likely hematite. This is also visible in the higher coercivity $\left(B_{\text {cr }}\right)$ of lake sediments in comparison with creek sediments (Table 3). As discussed earlier, acquisition of IRM (Fig. 10) and SEM/EDS analysis (Fig. 8) indicated that catchment rocks contained some hematite. The difference between creek sediments and lake sediments may be explainable by hydrodynamic sorting. Possibly, hematite grains occur as inclusions in lighter minerals, which are selectively washed away from the creek bedload and deposited on the lake floor, concentrating the large maghemitized titanomagnetite grains in creek sediments. Overlapping values in the Day plot (Fig. 12) indicate that lake sediments have a corresponding magnetic grain size distribution to that of creek sediments. However, the concentration of magnetic minerals is higher in sediments deposited during the Pliocene. As shown by Nowaczyk et al. (2002) and Murdock et al. (2013) using pilot cores PG1351 and LZ1029-7, 
respectively, the concentration of magnetite in the sediments of Lake El'gygytgyn is mainly controlled by the hypolimnetic redox conditions through large-scale magnetite dissolution during glacials and not simply by detrital input. Higher magnetic concentration during the Pliocene is therefore interpreted to reflect thorough mixing of lake water columns and weaker magnetite dissolution due to the warmer Pliocene climate in the Arctic (Brigham-Grette et al., 2013). Moreover, vivianite $\left(\mathrm{Fe}_{3}\left(\mathrm{PO}_{4}\right)_{2} \times 8 \mathrm{H}_{2} \mathrm{O}\right)$ nodules with relatively high susceptibility (mean value $1.05 \times 10^{-6} \mathrm{~m}^{3} \mathrm{~kg}^{-1}$ ) are present in sediments deposited during warm and cold climate stages (Minyuk et al., 2013), which may complicate paleoenvironmental interpretation of magnetic susceptibility in terms of paleoclimate, where cold intervals are expected to be characterized by low magnetic susceptibility. Thus, it is not possible to infer paleoenvironmental implications from mineral magnetic parameters alone. As shown by Frank et al. (2013) using pilot cores from Lake El'gygytgyn, statistical analysis of biochemical, inorganic and mineral magnetic data provides a more complete understanding of paleoenvironmental changes when refining the pattern of different climate modes in the sediments.

\section{Discussion}

Magnetic polarity stratigraphy reconstructed from the sediments from cores $1 \mathrm{~A}$ and $1 \mathrm{~B}$ from Lake El'gygytgyn compares favorably to the acknowledged geomagnetic polarity changes starting from the early Gauss chron to late Brunhes. The directional stability of the sediments, with partly maghemitized detrital PSD-sized titanomagnetite as the carrier of magnetization, enables reliable reconstruction of geomagnetic field changes from the sediments. The successful reconstruction of geomagnetic field changes during the Pleistocene and late Pliocene epochs comprises the main framework of geochronology for the sediments and enables pinning down of the age of fixed horizons along the sediment profile. These magnetostratigraphic tie points form the chronological frame for aligning (tuning) the different sediment climate proxy parameters with respect to orbital changes, which refines the temporal resolution of the sediment chronostratigraphy (Nowaczyk et al., 2013). A paleomagnetic composite record for Lake El'gygytgyn (Fig. 13) is amalgamated using data from cores $1 \mathrm{~A}, 1 \mathrm{~B}$, and $1 \mathrm{C}$ from Site 5011-1 and the sediments from 0 (i.e., the watersediment interface) to $5.67 \mathrm{~m}$ from core PG1351 from Lake El'gygytgyn (Nowaczyk et al., 2002), as the topmost sediment were not recovered during ICDP drilling. Composite depth values for polarity reversals and their respective ages are given in Table 4 . The high quality of the magnetostratigraphic record may appear somewhat astonishing when taking into account the climatically induced dissolution of magnetic minerals during glacials. Two scenarios can be speculated by which directional information can be
Table 4. Magnetostratigraphic tie points, their depth in the composite record from Site 5011-1 and their age (Ma) from LR04, except for the ages of the Cobb Mountain and Réunion cryptochrons, which are from Ogg and Smith (2004). Ages for the Intra-Jaramillo and Olduvai precursor events are derived from tuning with respect to the LR04 stack (Nowaczyk et al., 2013).

\begin{tabular}{lll}
\hline $\begin{array}{l}\text { Polarity chron, } \\
\text { subchron, } \\
\text { cryptochron }\end{array}$ & $\begin{array}{l}\text { Composite } \\
\text { depth (m) }\end{array}$ & Age (Ma) \\
\hline Brunhes/Matuyama & 31.710 & 0.780 \\
Jaramillo (t) & 41.530 & 0.991 \\
Jaramillo (b) & 44.110 & 1.073 \\
Cobb Mountain (t) & 47.800 & 1.175 \\
Cobb Mountain (b) & 48.125 & 1.185 \\
Olduvai (t) & 79.480 & 1.781 \\
Olduvai (b) & 88.425 & 1.968 \\
Reunion (t) & 100.630 & 2.128 \\
Reunion (b) & 101.150 & 2.148 \\
Matuyama/Gauss & 123.550 & 2.608 \\
Kaena (t) & $160.650^{*}$ & 3.045 \\
Kaena (b) & 163.500 & 3.127 \\
Mammoth (t) & 172.300 & 3.210 \\
Mammoth (b) & $197.400^{* *}$ & 3.319 \\
Impact & 319.700 & $3.580 \pm 0.04$ \\
\hline
\end{tabular}

* Low data quality prevents accurate determination of the termination of the Kaena subchron. ${ }^{* *}$ The depth value for the base of the Mammoth subchron represents a minimum value because of a gap in sediment recovery. Impact age is from data presented by Layer (2000).

preserved despite diagenetic changes associated with lake bottom anoxia: (1) magnetic particles became aligned to the field very quickly after deposition and subsequently part of them were dissolved within the sediment in reducing pore waters and (2) magnetic particles were already dissolved when settling down in the water column. The remaining particles, became aligned with the field and alignment was fixed in the sediment. In both cases directional information would be preserved. The first alternative is preferred, because relative paleointensity record cannot be reconstructed from the sediments. In case the second alternative would be true, depositional remanent magnetization should be proportional to field strength after normalizing for magnetic concentration variations, but this is not the case (Nowaczyk et al., 2002).

In comparison with the characteristic inclination records from cores $1 \mathrm{~A}$ and $1 \mathrm{~B}$, which extend $2.9 \mathrm{Myr}$ back in time, most of the polarity record from core $1 \mathrm{C}$ is rather noisy with the exception of sediments deposited during the early and late Gauss chron, when polarity is mainly normal (Fig. 7). There are several factors that can contribute to the noisier inclination record in core $1 \mathrm{C}$. Unlike cores $1 \mathrm{~A}$ and $1 \mathrm{~B}$, most of the sediment record covered by the core $1 \mathrm{C}$ does not have a duplicate. Technical problems during drilling of core 1C lead to incomplete sediment recovery (Melles et al., 2011). Moreover, extensive parts of the late Pliocene sediments are 


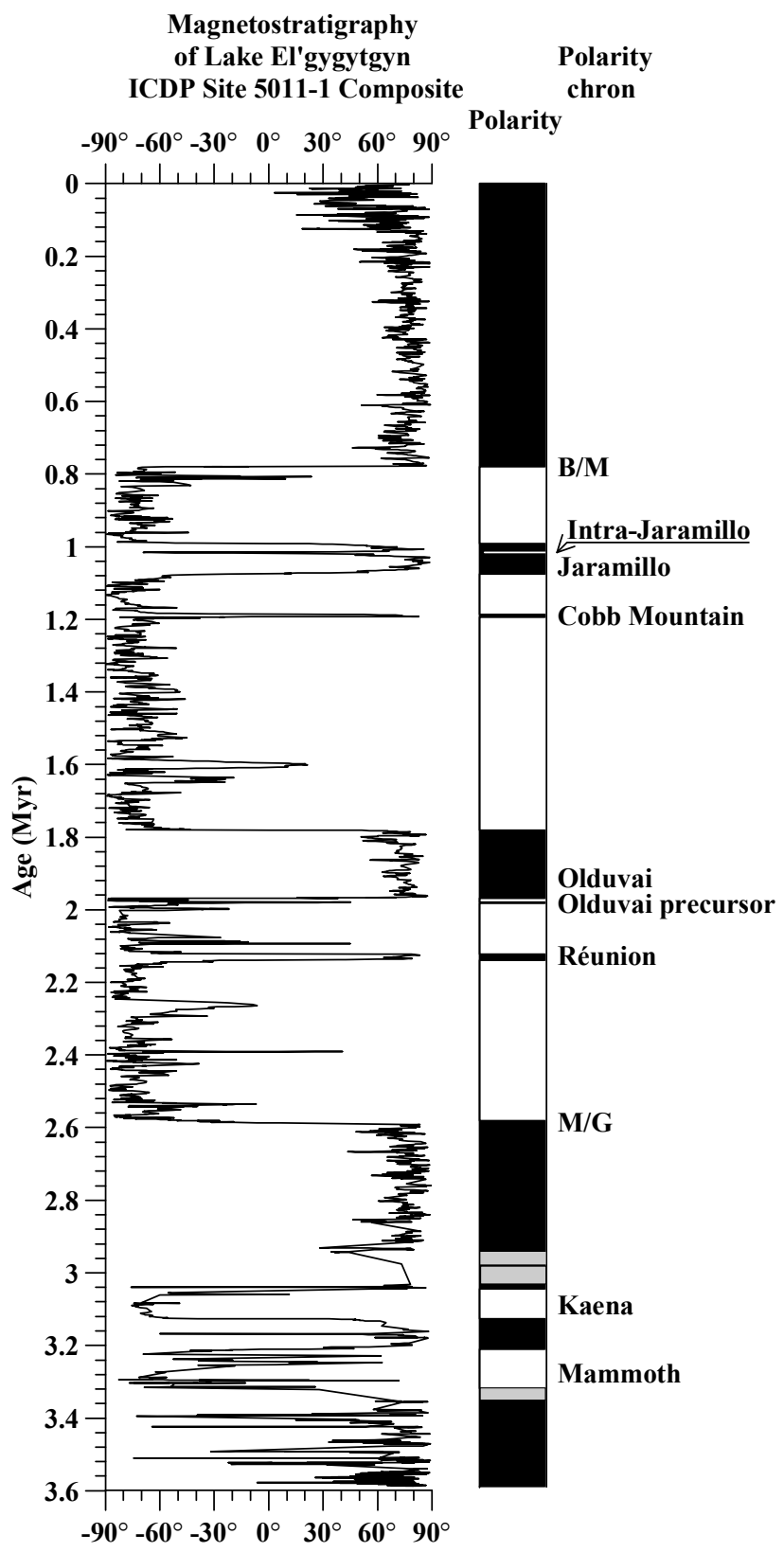

Fig. 13. Composite record of ChRM inclinations from ICDP Site 5011-1 in Lake El'gygytgyn. In the polarity column, black (white) [grey] denotes normal (reversed) [missing] polarity. Onset of the Mammoth subchron and termination of Kaena are somewhat ambiguous due to missing sediment and low data quality at these depths in the composite. Their reliability as tie points is not first-order.

characterized by sandy and gravelly layers, which are not ideal for recording geomagnetic field changes. Discrete samples yield point data, which may produce a noisy inclination record if, for example, the sampled sediment displays low NRM intensity, or there are localized but unnoticed disturbances in the sediment. By comparison, paleomagnetic measurements from $\mathrm{u}$-channels integrate data over sediment intervals $\sim 10 \mathrm{~cm}$ in length, which results in low-pass filtering of the paleomagnetic data, whereby localized disturbances do not stand out as much from the data (Roberts, 2006).

Nevertheless, the magnetostratigraphic interpretation of placing the onset of the Mammoth subchron in the paleomagnetic record in core $1 \mathrm{C}$ is supported by paleoenvironmental proxy data. Interpreting results from pollen analysis (Tarasov et al., 2013) supports the chronological constrains set by magnetostratigraphy. Coinciding with the anticipated early Mammoth subchron, pollen data indicate a change in the paleoenvironment of Lake El'gygytgyn into cold and drought tolerant climate regime with steppe vegetation. MIS M2 occurs in the early Mammoth subchron, and in previous studies MIS M2 has been connected with a global cooling event and an increase in ice volume (Dwyer and Chandler, 2009; Schepper et al., 2009). In consequence, the occurrence of plant taxa indicating cooler climate at about 3.3 Ma in core $1 \mathrm{C}$ is interpreted to be coeval with MIS M2, and thus supports the interpretation of magnetostratigraphic data from Lake El'gygytgyn.

The completeness of the ICDP Site 5011-1 magnetostratigraphic record (Fig. 13), which shows all the widely acknowledged magnetic polarity chrons, subchrons, the cryptochrons Réunion and Cobb Mountain and even two excursions, attests to the absence of any major hiatuses in the sediment record. This adds to the debate of the glacial history of Western Beringia and to the evidence presented by (Brigham-Grette et al., 2003) in support of an ice sheet-free Far East Russia since the Middle Pleistocene.

Using the present paleomagnetic approach, the age of the El'gygytgyn impact structure can be loosely bracketed between the onset of the Mammoth subchron at 3.319 Ma onset of the Gauss chron, which Ogg and Smith (2004) place at 3.588 Ma. In the base of the sequence at ICDP Site 5011-1, sediments show a consistently normal polarity, which suggests that these sediments are definitely younger than the $\mathrm{G} / \mathrm{G}$ polarity reversal $(3.588 \mathrm{Ma})$, which sets the age of the impact to the younger end in the error margin of $3.58 \pm 0.04$ reported by Layer (2000). Previous work using fission track dating placed the corrected age estimate of the structure at 4.52 $\pm 0.11 \mathrm{Ma}$ (Storzer and Wagner, 1979). An even older result from K/Ar dating was proposed by Belyi (1998), who suggested that volcanic activity in the area between $5.8 \pm 0.5 \mathrm{Ma}$ and $8.4 \pm 0.7 \mathrm{Ma}$ would have given rise to the structure. In the light of first-time paleomagnetic results from the present study, the results both from fission track and K/Ar dating can be taken as inaccurate, and it can be concluded that results from ${ }^{40} \mathrm{Ar} /{ }^{39} \mathrm{Ar}$ dating (Layer, 2000) presently give the most accurate estimate of the age of the impact.

Using the magnetic polarity chronology, general variations in sediment deposition rate from the late Pliocene to the late Pleistocene can be outlined. In the early history of the crater, in the time period between the impact at $3.58 \pm 0.04 \mathrm{Ma}$ 
(Layer, 2000) and the onset of the Mammoth subchron at $3.319 \mathrm{Ma}$, the mean sedimentation rate was an order of magnitude higher $\left(\sim 44 \mathrm{~cm} \mathrm{kyr}^{-1}\right)$ compared to the sediments accumulated since the beginning of the Pleistocene and until the most recent part of the record (Fig. 14). The Early and Middle Pliocene climate in the Arctic was warmer and moister than the present (Salzmann et al., 2011), as characterized, for example, by the presence of boreal forests on Ellesmere Island (Ballantyne et al., 2006). The moister Pliocene climate can be postulated to have promoted fluvial supply of detrital matter from the lake catchment to the basin, as witnessed in the higher sedimentation rates in comparison with those reconstructed for the Pleistocene. The shift from the Pliocene to the Pleistocene, in general, is associated with reorganization of atmospheric and oceanic circulation patterns, leading to global paleoenvironmental changes, as evidenced, for example, by the formation of Northern Hemisphere ice sheets (Raymo, 1994) and large-scale aridification in the subtropical latitudes on both hemispheres (deMenocal, 2004; McLaren and Wallace, 2010). Therefore, the deceleration of sedimentation in Lake El'gygytgyn relates to the reorganization of atmospheric circulation over the circumpolar area through changes in surface hydrologic processes, decreasing thickness of soil active layer and formation of permafrost and thus it reflects in part the sensitivity of the El'gygytgyn sedimentary record to climatic change (Schwamborn et al., 2012). However, the high sedimentation rates, which fill in the basin rapidly in the early history of the crater, are probably also promoted by geological processes. The newly formed outer crater rim structure with unstable steep inner flanks, which rose up to $230 \mathrm{~m}$ above the present lake level, provided abundant erodible clastic material (Gurov and Koeberl, 2004), increasing the flux of clastic material into the lake. During the late Quaternary, lake water table changes followed climatic variability, with higher levels inferred to have occurred during warmer periods (Juschus et al., 2011). Anticipated high water tables during Pliocene times likely promoted the input of detrital matter from the catchment by enhanced wave action in the first $\sim 200 \mathrm{kyr}$ since the crater formation. During this time, sediment deposition rate is at its highest. After this initial stage in sediment deposition in Lake El'gygytgyn the sedimentation slows down significantly.

Lower sedimentation rates during the Pleistocene probably prolonged the magnetization lock-in time in Lake El'gygytgyn sediments and thus decreased the temporal resolution of the obtained paleomagnetic data. This might be the reason why most of the geomagnetic excursions documented to have taken place during the Matuyama and Brunhes chrons (e.g., Laj and Channell, 2007) are missing in the ICDP Site 5011-1 record, except for Olduvai precursor and the Intra-Jaramillo excursions. In addition to low sedimentation rates, the position of Lake El'gygytgyn may decrease the probability of very short-term geomagnetic changes of being recorded, because polarity change is anticipated to take

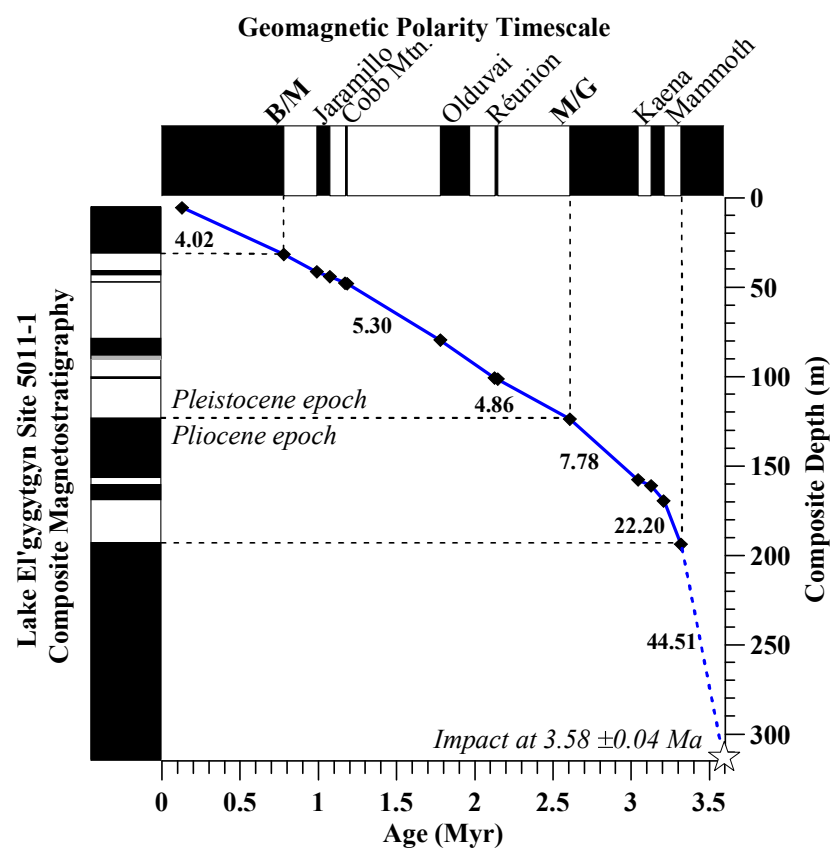

Fig. 14. Age-depth curve of the composite record (in blue) based on stratigraphical tie points (black diamonds) provided by the magnetostratigraphy. Age of the impact (Layer, 2000) denoted with a star forms an additional chronological tie point. Numbers in boxes refer to sedimentation rates $\left(\mathrm{cm} \mathrm{kyr}^{-1}\right)$ in different intervals of the composite record.

a longer time at high-latitude sites compared to lower latitudes (Clement, 2004). However, the presence of the Olduvai precursor and Intra-Jaramillo excursions, which last only 3.3 and $5 \mathrm{kyr}$, respectively (Nowaczyk et al., 2013), suggests that even higher frequency variations in the geomagnetic field can be recorded in favorable conditions at highlatitude sites. The more scattered inclination record, and less clear-cut polarity boundaries during the Pliocene in comparison with those in the Pleistocene may also be due to higher sedimentation rates during the Pliocene, which allow a more detailed recording of the transitional geomagnetic field configuration during reversals.

\section{Conclusions}

Sediment cores recovered from the three holes 1A, 1B, and 1C from ICDP Site 5011-1 in Lake El'gygytgyn, Far East Russian Arctic, provide a reliable record of geomagnetic polarity variations during the last approximately $3.58 \mathrm{Myr}$. Remanence is carried by partly maghemitized PSD-size titanomagnetite derived from the lake catchment and transported by numerous creeks, which discharge into the lake. Correlation of the reconstructed magnetostratigraphy from Site 5011-1 with the reference curve (LR04) provides a total of 12 first-order reversal horizons to pin down the sediment chronostratigraphy of the longest sediment record from 
the continental Arctic. In the base of the record, sedimentation rate is an order of magnitude higher $\left(44.5 \mathrm{~cm} \mathrm{kyr}^{-1}\right)$ compared to sediments deposited during the Pleistocene. Deceleration of sedimentation rate is interpreted as responding to hydrological changes associated with Quaternary climate cooling and geological development of the crater structure. This magnetostratigraphic study rules out the incidence of the impact, which formed the El'gygytgyn meteorite crater, prior to the early Gauss chron.

Acknowledgements. We would like to thank the participants in the lake drilling campaign in 2008/2009 for recovering the long sediment cores from Lake El'gygytgyn. O. Juschus and G. Schwamborn provided sample material from the El'gygytgyn catchment. G. Arnold prepared the polished rock sections. H. Kemnitz and J. Herwig provided technical assistance at the SEM/EDS facility. A team of student assistants at the Department of Geology, University of Cologne, sampled sediments in u-channels. R. Gromig participated in paleomagnetic sampling using discrete paleomagnetic boxes. D. Ulbricht, G. Schwamborn and $\mathrm{V}$. Wennrich transported $\mathrm{u}$-channel samples from Cologne to Potsdam. L. Brown and an anonymous reviewer provided thoughtful reviews. Funding for this research was provided by the International Continental Scientific Drilling Program (ICDP), the US National Science Foundation (NSF), the German Federal Ministry of Education and Research (BMBF), the Alfred Wegener Institute (AWI) and GeoForschungsZentrum Potsdam (GFZ), the Russian Academy of Sciences Far East Branch (RAS FEB), the Russian Foundation for Basic Research (RFBR), and the Austrian Federal Ministry of Science and Research (BMWF). The Russian GLAD800 drilling system was developed and operated by DOSECC Inc., the down hole logging was performed by the ICDP-OSG, and LacCore, at the University of Minnesota, handled core curation.

The service charges for this open access publication have been covered by a Research Centre of the Helmholtz Association.

Edited by: J. Brigham-Grette

\section{References}

Akimoto, T., Kinoshita, H., and Furuta, T.: Electron probe microanalysis study on processes of low- temperature oxidation of titanomagnetite, Earth Planet. Sc. Lett., 71, 263-278, 1984.

Ballantyne, A. P., Rybczynski, N., Baker, P. A., Harington, C. R., and White, D.: Pliocene Arctic temperature constraints from the growth rings and isotopic composition of fossil larch, Palaeogeogr. Palaeocl., 242, 188-200, 2006.

Belyi, V. F.: Impactogenesis and volcanism of the El'gygytgyn depression, Petrology, 6, 86-99, 1998.

Brigham-Grette, J., Gualtieri, L. M., Glushkova, O. Y., Hamilton, T. D., Mostoller, D., and Kotov, A.: Chlorine-36 and 14C chronology support a limited last glacial maximum across central chukotka, northeastern Siberia, and no Beringian ice sheet, Quaternary Res., 59, 386-398, 2003.
Brigham-Grette, J., Melles, M., Minyuk, P., and Scientific Party: Overview and significance of a $250 \mathrm{ka}$ paleoclimate record from El'gygytgyn Crater Lake, NE Russia, J. Paleolimnol., 37, 1-16, 2007.

Brigham-Grette, J., Melles, M., Minyuk, P., Andreev, A., Tarasov, P., DeConto, R., Koenig, S., Nowaczyk, N., Wennrich, V., Rosén, P., Haltia-Hovi, E., Cook, T., Gebhardt, C., Meyer-Jacob, C., Snyder, J., and Herzschuh, U.: Pliocene warmth, polar amplification, and stepped Pleistocene cooling recorded in NE Arctic Russia, Science, 340, 1421-1427, 2013.

Cande, S. C. and Kent, D. V.: Revised calibration of the geomagnetic polarity timescale for the Late Cretaceous and Cenozoic, J. Geophys. Res., 100, 6093-6095, 1995.

Chamalaun, F. H. and McDougall, I.: Dating geomagnetic polarity epochs in Réunion, Nature, 210, 1212-1214, 1966.

Channell, J. E. T. and Kleiven, H. F.: Geomagnetic palaeointensities and astrochronological ages for the Matuyama-Brunhes boundary and the boundaries of the Jaramillo Subchron: palaeomagnetic and oxygen isotope records from ODP Site 983, Philos. T. Roy. Soc. A, 358, 1027-1047, 2000.

Channell, J. E. T., Mazaud, A., Sullivan, P., Turner, S., and Raymo, M. E.: Geomagnetic excursions and paleointensities in the Matuyama Chron at Ocean Drilling Program Sites 983 and 984 (Iceland Basin), J. Geophys. Res., 107, EPM 1.1-EPM 1.14, doi:10.1029/2001JB000491, 2002.

Channell, J. E. T., Labs, J., and Raymo, M. E.: The Réunion Subchronozone at ODP Site 981 (Feni Drift, North Atlantic), Earth Planet. Sc. Lett., 215, 1-12, 2003.

Clement, B. M.: Dependence of the duration of geomagnetic polarity reversals on site latitude, Nature, 428, 637-640, 2004.

Cui, Y., Verosub, K. L., and Roberts, A. P.: The effect of lowtemperature oxidation on large multi-domain magnetite, Geophys. Res. Lett., 21, 757-760, 1994.

Day, R., Fuller, M., and Schmidt, V. A.: Hysteresis properties of titanomagnetites: grain-size and compositional dependence, Phys. Earth Planet. Int., 13, 260-267, 1977.

Dearing, J. A., Boyle, J. F., Appleby, P. G., Mackay, A. W., and Flower, R. J.: Magnetic properties of recent sediments in Lake Baikal, Siberia, J. Paleolimnol., 20, 163-173, 1998.

deMenocal, P. B.: African climate change and faunal evolution during the Pliocene-Pleistocene, Earth Planet. Sc. Lett., 220, 3-24, 2004.

Dunlop, D. J.: Theory and application of the Day plot $\left(M_{\mathrm{rs}} / M_{\mathrm{S}}\right.$ versus $\left.H_{\mathrm{cr}} / H_{\mathrm{c}}\right)$, 1 . Theoretical curves and tests using titanomagnetite data, J. Geophys. Res., 107, 2056, doi:10.1029/2001JB000486, 2002.

Dwyer, G. S. and Chandler, M. A.: Mid-Pliocene sea level and continental ice volume based on coupled benthic $\mathrm{Mg} / \mathrm{Ca}$ palaeotemperatures and oxygen isotopes, Philos. T. Roy. Soc. A, 367, 157$168,2009$.

Fedorov, G., Nolan, M., Brigham-Grette, J., Bolshiyanov, D., Schwamborn, G., and Juschus, O.: Preliminary estimation of Lake El'gygytgyn water balance and sediment income, Clim. Past, 9, 1455-1465, doi:10.5194/cp-9-1455-2013, 2013.

Frank, U., Nowaczyk, N. R., Minyuk, P., Vogel, H., Rosén, P., and Melles, M.: A $350 \mathrm{ka}$ record of climate change from Lake El'gygytgyn, Far East Russian Arctic: refining the pattern of climate modes by means of cluster analysis, Clim. Past, 9, 15591569, doi:10.5194/cp-9-1559-2013, 2013. 
Gebhardt, A. C., Niessen, F., and Kopsch, C.: Central ring structure identified in one of the world's best-preserved impact craters, Geology, 34, 145-148, 2006.

Gebhardt, A. C., Francke, A., Kück, J., Sauerbrey, M., Niessen, F., Wennrich, V., and Melles, M.: Petrophysical characterization of the lacustrine sediment succession drilled in Lake El'gygytgyn, Far East Russian Arctic, Clim. Past, 9, 1933-1947, doi:10.5194/cp-9-1933-2013, 2013.

Guo, B., Zhu, R., Florindo, F., Ding, Z., and Sun, J.: A short, reverse polarity interval within the Jaramillo subchron: Evidence from the Jingbian section, northern Chinese Loess Plateau, J. Geophys. Res., 107, EPM 2-1-EPM 2-12, doi:10.1029/2001JB000706, 2002.

Gurov, E. P. and Koeberl, C.: Shocked rocks and impact glasses from the El'gygytgyn impact structure, Russia, Meteorit. Planet. Sci., 39, 1495-1508, 2004.

Hunt, C. P., Moskowitz, B. M., and Banerjee, S. K.: Magnetic Properties of Rocks and Minerals, in: Rock Physics and Phase Relations A Handbook of Physical Constants, AGU Reference Shelf 3, 189-204, 1995.

Juschus, O., Pavlov, M., Schwamborn, G., Preusser, F., Fedorov, G., and Melles, M.: Late Quaternary lake-level changes of Lake El'gygytgyn, NE Siberia, Quaternary Res., 76, 441-451, 2011.

Katz, S. L., Hampton, S. E., Izmest' eva, L. R., and Moore, M. V.: Influence of Long-Distance Climate Teleconnection on Seasonality of Water Temperature in the World's Largest Lake - Lake Baikal, Siberia, PLoS one, 6, e14688, doi10.1371/journal.pone.0014688, 2011.

Kirschvink, J. L.: The least-squares line and plane and the analysis of palaeomagnetic data, Geophys. J. Int., 62, 699-718, 1980.

Kutzbach, J. E., Gallimore, R. G., and Guetter, P. J.: Sensitivity experiments on the effect of orbitally-caused insolation changes on the interglacial climate of high northern latitudes, Quatern. Int., 10-12, 223-229, 1991.

Laj, C. and Channell, J. E. T.: Geomagnetic Excursions, in: Treatise on Geophysics, 5 Geomagnetism, edited by: Kono, M., Elsevier, 373-416, 2007.

Laskar, J., Robutel, P., Joutel, F., Gastineau, M., Correia, A. C. M., and Levrard, B.: A long-term numerical solution for the insolation quantities of the Earth, Astron. Astrophys., 428, 261-285, 2004

Layer, P. W.: Argon-40/argon-39 age of the El'gygytgyn impact event, Chukotka, Russia, Meteor. Planet. Sci., 35, 591-600, 2000.

Lisiecki, L. E. and Raymo, M. E.: A Pliocene-Pleistocene stack of 57 globally distributed benthic $\delta \mathrm{O}$ records, Paleoceanography, 20, PA1003, doi:10.1029/2004PA001071, 2005.

Lozhkin, A., Anderson, P., Matrosova, T., and Minyuk, P.: The pollen record from El'gygytgyn Lake: implications for vegetation and climate histories of northern Chukotka since the late middle Pleistocene, J. Paleolimnol., 37, 135-153, 2007.

Maher, B. A.: The magnetic properties of Quaternary aeolian dusts and sediments, and their palaeoclimatic significance, Aeolian Res., 3, 87-144, 2011.

Mankinen, E. A., Donnelly, J. M., and Grommé, C. S.: Geomagnetic Polarity Event Recorded at 1.1 M.y. B.P. on Cobb Mountain, Clear Lake Volcanic Field, California, Geology, 6, 653-656, 1978.
Marshall, M. and Cox, A.: Magnetic Changes in Pillow Basalt Due to Sea Floor Weathering, J. Geophys. Res., 77, 6459-6469, 1972.

McLaren, S. and Wallace, M. W.: Plio-Pleistocene climate change and the onset of aridity in southeastern Australia, Global Planet. Change, 71, 55-72, 2010.

Melles, M., Minyuk, P., Brigham-Grette, J., and Juschus, O. (Eds.): The Expedition El'gygytgyn Lake 2003 (Siberian Arctic), Number 505, Berichte zur Polar- und Meeresforschung, 139 pp., 2005.

Melles, M., Brigham-Grette, J., Minyuk, P., Koeberl, C., Andreev, A., Cook, T., Fedorov, G., Gebhardt, C., Haltia-Hovi, E., Kukkonen, M., Nowaczyk, N., Schwamborn, G., Wennrich, V., and El'gygytgyn Scientific Party: The Lake El'gygytgyn Scientific Drilling Project - Conquering Arctic Challenges through Continental Drilling, Scientific Drill., 11, 29-40, 2011.

Melles, M., Brigham-Grette, J., Minyuk, P. S., Nowaczyk, N. R., Wennrich, V., DeConto, R., Anderson, P. M., Andreev, A. A., Coletti, A., Cook, T. L., Haltia-Hovi, E., Kukkonen, M., Lozhkin, A. V., Rosén, P., Tarasov, P., Vogel, H., and Wagner, B.: 2.8 Million years of Arctic climate change from Lake El'gygytgyn, NE Russia, Science, 337, 315-320, 2012.

Minyuk, P. S., Subbotnikova, T. V., Brown, L. L., and Murdock, K. J.: High-temperature thermomagnetic properties of vivianite nodules, Lake El'gygytgyn, Northeast Russia, Clim. Past, 9, 433-446, doi:10.5194/cp-9-433-2013, 2013.

Murdock, K. J., Wilkie, K., and Brown, L. L.: Rock magnetic properties, magnetic susceptibility, and organic geochemistry comparison in core LZ1029-7 Lake El'gygytgyn, Russia Far East, Clim. Past, 9, 467-479, doi:10.5194/cp-9-467-2013, 2013.

Nolan, M. and Brigham-Grette, J.: Basic hydrology, limnology, and meteorology of modern Lake El'gygytgyn, Siberia, J. Paleolimnol., 37, 17-35, 2007.

Nowaczyk, N. R.: Dissolution of titanomagnetite and sulphidization in sediments from Lake Kinneret, Israel, Geophys. J. Int., 187, 34-44, 2011.

Nowaczyk, N. R., Minuyk, P., Melles, M., Brigham-Grette, J., Glushkova, O., Nolan, M., Lozhkin, A. V., Stetsenko, T. V., Andersen, P. M., and Forman, S. L.: Magnetostratigraphic results from impact crater Lake El'gygytgyn, northeastern Siberia: a $300 \mathrm{kyr}$ long high-resolution terrestrial palaeoclimatic record from the Arctic, Geophys. J. Int., 150, 109-126, 2002.

Nowaczyk, N. R., Melles, M., and Minyuk, P.: A revised age model for core PG1351 from Lake El'gygytgyn, Chukotka, based on magnetic susceptibility variations tuned to northern hemisphere insolation variations, J. Paleolimnol., 37, 65-76, 2007.

Nowaczyk, N. R., Haltia, E. M., Ulbricht, D., Wennrich, V., Sauerbrey, M. A., Rosén, P., Vogel, H., Francke, A., MeyerJacob, C., Andreev, A. A., and Lozhkin, A. V.: Chronology of Lake El'gygytgyn sediments - a combined magnetostratigraphic, palaeoclimatic and orbital tuning study based on multiparameter analyses, Clim. Past, 9, 2413-2432, doi:10.5194/cp-92413-2013, 2013.

Ogg, J. G. and Smith, A. G.: The geomagnetic polarity time scale, in: A Geologic Time Scale 2004, edited by: Gradstein, F. M., Ogg, J. G., and Smith, A. G., Cambridge University Press, 2004.

Opdyke, N. D. and Channell, J. E. T.: Magnetic stratigraphy, International Geophysics, Academic Press, San Diego, 1996.

Parry, L. G.: Shape-related factors in the magnetization of immobilized magnetite particles, Phys. Earth Planet. Int., 22, 144-154, 1980. 
Peters, C. and Dekkers, M. J.: Selected room temperature magnetic parameters as a function of mineralogy, concentration and grain size, Phys. Chem. Earth, 28, 659-667, 2003.

Pillans, B. J., Roberts, A. P., Wilson, G. S., Abbott, S. T., and Alloway, B. V.: Magnetostratigraphic, lithostratigraphic and tephrostratigraphic constraints on Lower and Middle Pleistocene sea-level changes, Wanganui Basin, New Zealand, Earth Planet. Sc. Lett., 121, 81-98, 1994.

Raymo, M. E.: The initiation of northern hemisphere glaciation, Annu. Rev. Earth Pl. Sc., 22, 353-383, 1994.

Roberts, A. P.: High-resolution magnetic analysis of sediment cores: Strengths, limitations and strategies for maximizing the value of long-core magnetic data, Phys. Earth Planet. Int., 156, 162-178, 2006.

Roberts, A. P. and Weaver, R.: Multiple mechanisms of remagnetization involving sedimentary greigite (Fe3S4), Earth Planet. Sc. Lett., 231, 263-277, 2005.

Salzmann, U., Williams, M., Haywood, A. M., Johnson, A. L. A., Kender, S., and Zalasiewicz, J.: Climate and environment of a Pliocene warm world, Palaeogeogr. Palaeocl., 309, 1-8, 2011.

Sauerbrey, M. A., Juschus, O., Gebhardt, A. C., Wennrich, V., Nowaczyk, N. R., and Melles, M.: Mass movement deposits in the 3.6 Ma sediment record of Lake El'gygytgyn, Far East Russian Arctic, Clim. Past, 9, 1949-1967, doi:10.5194/cp-9-19492013, 2013.

Schepper, S. D., Head, M. J., and Groeneveld, J.: North Atlantic Current variability through marine isotope stage M2 (circa 3.3 Ma) during the mid-Pliocene, Paleoceanography, 24, PA4206, doi:10.1029/2008PA001725, 2009.
Schwamborn, G., Fedorov, G., Ostanin, N., Schirrmeister, L., Andreev, A., and the El'gygytgyn Scientific Party: Depositional dynamics in the El'gygytgyn Crater margin: implications for the 3.6 Ma old sediment archive, Clim. Past, 8, 1897-1911, doi:10.5194/cp-8-1897-2012, 2012.

Snowball, I. F.: Magnetic hysteresis properties of greigite (Fe3S4) and a new occurrence in Holocene sediments from Swedish Lappland, Phys. Earth Planet. Int., 68, 32-40, 1991.

Storzer, D. and Wagner, G. A.: Fission Track Dating of Elgygytgyn, Popigai and Zhamanshin Impact Craters: No Sources for Australasian or North-American Tektites, Meteoritics, 14, 541-542, 1979.

Tarasov, P. E., Andreev, A. A., Anderson, P. M., Lozhkin, A. V., Leipe, C., Haltia, E., Nowaczyk, N. R., Wennrich, V., BrighamGrette, J., and Melles, M.: A pollen-based biome reconstruction over the last 3.562 million years in the Far East Russian Arctic new insights into climate-vegetation relationships at the regional scale, Clim. Past, 9, 2759-2775, doi:10.5194/cp-9-2759-2013, 2013.

Thompson, R. and Oldfield, F.: Environmental Magnetism, Allen and Unwin, London, 227 pp., 1986.

Wennrich, V., Minyuk, P. S., Borkhodoev, V. Ya., Francke, A., Ritter, B., Nowaczyk, N., Sauerbrey, M. A., Brigham-Grette, J., and Melles, M.: Pliocene to Pleistocene climate and environmental history of Lake El'gygytgyn, Far East Russian Arctic, based on high-resolution inorganic geochemistry data, Clim. Past Discuss., 9, 5899-5940, doi:10.5194/cpd-9-5899-2013, 2013. 